أثر برنامج للتدريب النفسي المدعم بوسائل تكنولوجية على بعض المهارات النفسية ومستوى الأداء لدى لاعبي تنس الطاولة

\author{
ميرفت عاهد ذيب و هاشم عدنان الكيلاني \\ dr_mervat_deeb2005@yahoo \\ جامعة البلقاء التطبيقية، الأردن جامعة السلطان قابوس، سلطنة عمان
}

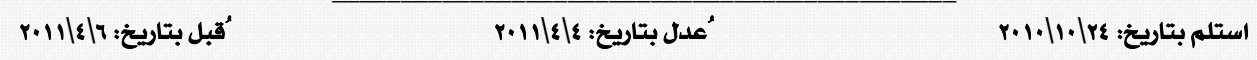

هدفت الدراسة إلى التعرف على أثر برنامج نفسي والمدعم بوسائل تكنولوجية (Macromedia Flash)على بعض مهارات الإعداد

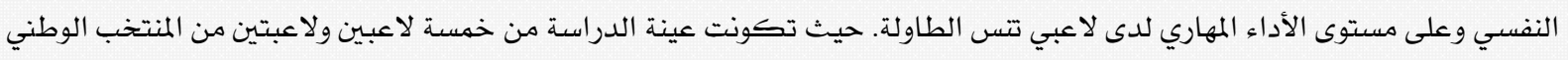

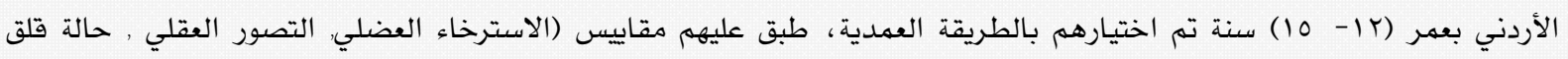
المنافسة, استمارة استكشاف الحديث مع الذات واختبار تركيز الانتباه الملون الخاص بلاعبي تتس الطاولة) كما تم تقييم الأداء المهاري أثناء المنافسة خلال استهارة اسلمارة خاصة.

استخدم الباحثان المنهج التجريبي ذو المجموعة الواحدة والذي يحاكي ظروف المنافسة وقد استفرق تطبيق البرنامج (Y أسبوع) بواقع أربع جلسات تدريبية وِ الأسبوع. ولتحليل النتائج استخدم اختبار ويلكوكسون Welcoxon لفروق الرتب بين القياسين القبلي

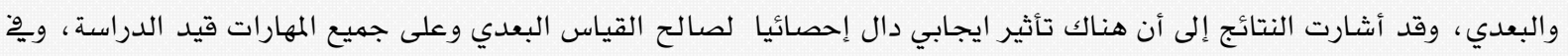

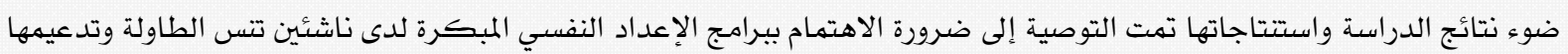
مع الأداء العملي بوصفها جزأ لا يتجزأ من الإعداد المتكامل للاعبين والى استخدام قياسـات نفسية ومهارية أخرى للوقوف على حالى حالة

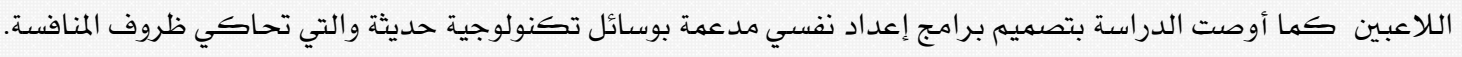

$$
\text { الكلمات الدالة : ماكروميديا فلاش، الإعداد النفسي، تتس الطاولة }
$$

\title{
Effect of Psychological Conditioning Supported with Technology on Some Psychological Skills Tennis Players and Level of Performance for Table Mervat Ahed Deeb \& Hashem Adnan Kilani
}

\author{
Al- Balqa A pplied University, Jordan Sultan Qaboos University, Sultanate of Oman
}

The purpose of the study was to detect the effect of a psychological program supported by Macromedia Flash technology on some of psychological conditioning skills and the level of skills performance for table tennis players. Seven subjects comprised of 5 male and 2 female players from the Jordan national team with age ranges $12-15$ year of old were intentionally selected. M easurement of muscle relaxation, mental imagery, state of competition anxiety, self talk, and colored readiness concentration (in-house built) for table tennis players. Skill performance during the competition was also assessed using special forms. Experiment design involved one group with pre and post hoc test after 12 weeks of the program application, 4 sessions per week in a simulated competition circumstances. Results of none parametric statistics (Welcoxon) revealed that there was a significant effect of the program at post hoc test for all skills variables. It is imperative to provide an early psychological conditioning program for table tennis juniors' players with practice sessions as it is important part of training regimen. In addition, it was suggested to use the Macromedia Flash technology for simulation enhancement of the real competition.

Key words: Macromedia Flash, Psychological Conditioning, Table Tennis. 
et al., 1996، Weinberg, 1988) وبناء الأهداف، .(Vealey, 1988، Hardy

إن الفائدة مـن مثنل هذه البرامج تمتـد لنتـمل المبتدئين والناشئين (راتب ع . . r) واءن هناك مهارات نفسية نساعد في النجاح في الألعاب الرياضية, ولكن

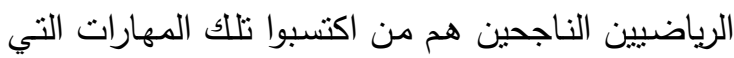
من خلالها يمكن أن يحسنوا مستواهم بالتعلم والممارسة.

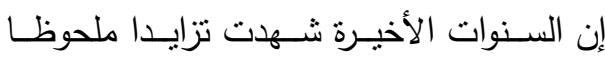
لاشتراك الناشئين في برامج التدريب والمنافسة وينوقع أن تصاحب تلك الزيادة أحمال وضغوط تدريب مكثفة قد بد

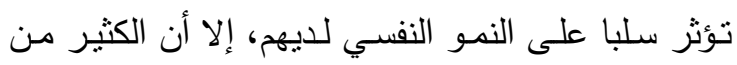

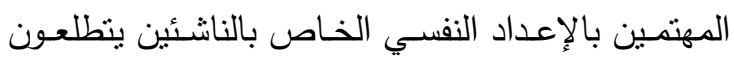

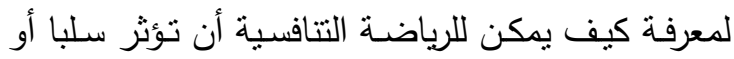

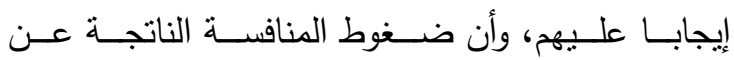
المشاركة المكثفة والتدريب الثاق يؤديان إلى زيادة القلق والتوتز مقابل نقص فائدة وقيمـة الاشتراك في المنافسـة

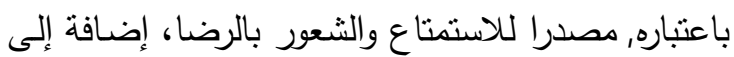

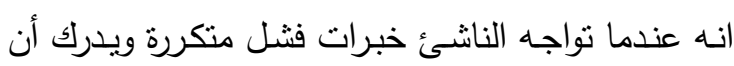
الفتل هو نتيجة أدائه فإن ذلك يفقده التقة بالنفس، لأن هذا التقييم السلبي لذاته يزيد من شعوره بعدم كفاءته،

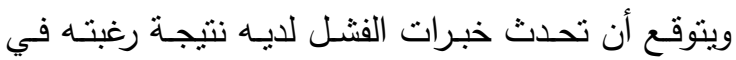

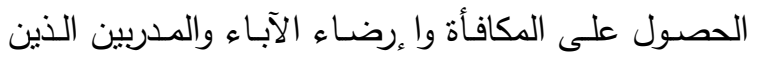
يضـون أهدافا تفوق قدرات الناشسئ. ويحدث أحيانـا أن تمثل تلك الضغوط مشكلة كبيرة لديه، فلا تنجح معها جهود المدربين أو الآبـاء في التأكيد على قيمـة الذات. وعندها تبرز الحاجة إلى تعلم مهارات نفسية لمواجهة ضغوط المنافسة ومنها: التصور العقلي وتركيز الانتباه وبناء الأهداف والتقة بالنفس والحديث مـع الذات "التحكم

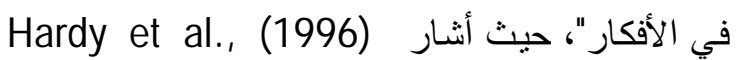
إلى أن أسـاليب الإعداد النفسي كالاسترخاء, والتصـور العقلي, والحديث مع الذات, هي أكثر من مجرد وسائل,

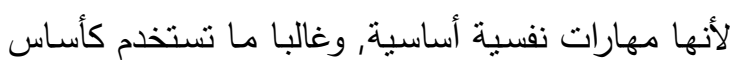

إن مســتوى الأداء فــي الألعــاب الجماعيــة

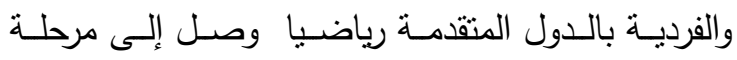
الأداء الفائق المتميز في جميع النواحي البدنية والمهارية والنفسية، وهذا لم يـأت وليد الصدفة ولكن مـن خـلاهل

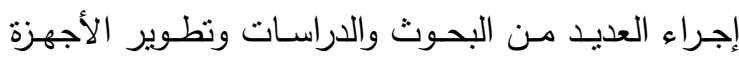

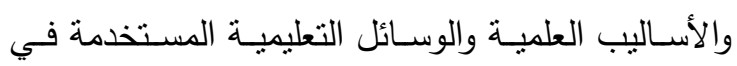
تدريب اللاعبين للوصول لأعلى مستوى من التميز الذي

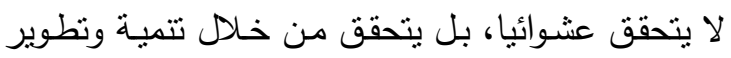

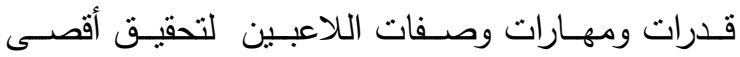

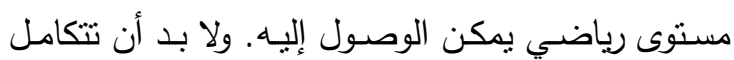

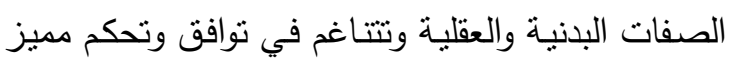
حتى يتحقق الانجاز العالي حيث يشبر راتب، (ع . . r)

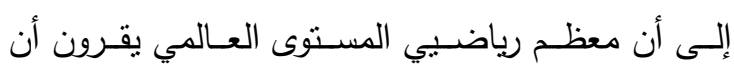

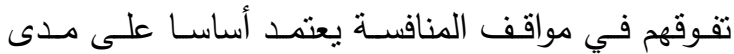

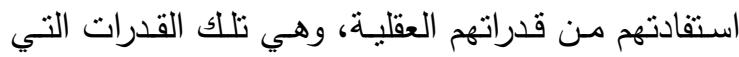
تجعلهم يستطيعون تعبئة طاقاتهم لأقصى درجة مدكنة.

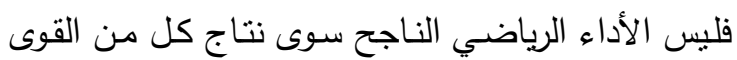

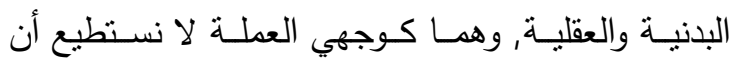
نفصل بينهما ـ والواقع العلمي يؤكد أن الاهتمام بالإعداد

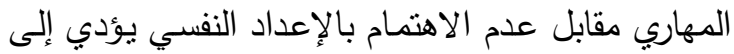

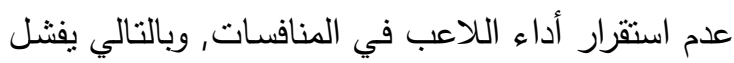

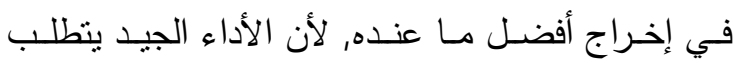
قدرات عقلية تكون بنفس مستوى القدرات البدنية. إن معظم النظريات والبحوث الخاصـة بتطوير الأداء في علم النفس الرياضي تقوم على الافتراض بأن العوامل النفسية هي محددات مهمة للأداء في الرياضـة.

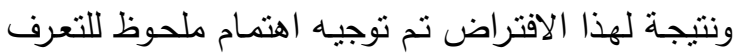
علـى المهــارات النفسـية المتاحسة لإرشــاد المــدربين والرياضيين حـول كيفيـة تعليم وتطبيق هذه المهارات, ولابــــ ان تتضــمن بـرامج التــريب البـدني والمهــاري والخططي، وكذللك المهـارات النفسـية التاليـة: التصــور العقلي وتتظيم الطاقـة واءدارة الضـغوط وتركيز الانتبـاه 
الناتج عن استنزاف الطاقة يجعل العضلة تعدل بشكل

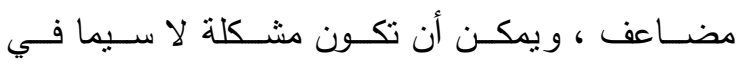

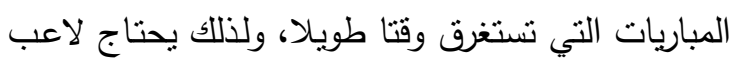
تتس الطاولة إلى الاسترخاء العضلي، والذي يعد بالتالي لئي مدخلا مهما لعملية التصور العقلي.

أما التصور العقلي فيعتبر مهارة نفسية (عقلية) وأحـد الأسـاليب النفسـية، ذلـك أن في عمليـة التصـور

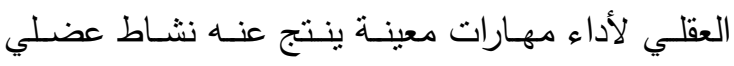
معين ريما يكون محدودا ولكن فائدنه تتضـح في ثقوية

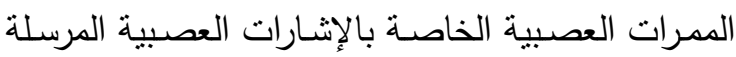
مــن الجهــاز العصــبـي إلـــى العضـــلات العاملــــة

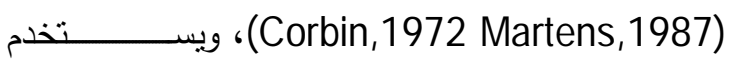
التصـور العقلِي الحـواس المختلفـة لاستحضــار الصـورة

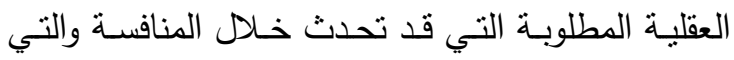
يمكن مسن خلالهـا الـتحكم فـي الانفعـالات والأفكـار والتزكيز على الرموز (Cue Words) الموجهة للمهام،

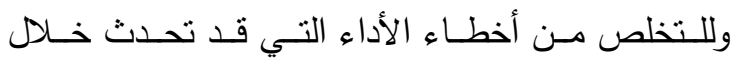

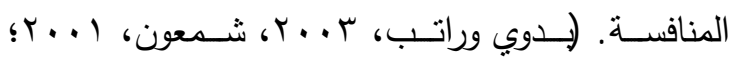

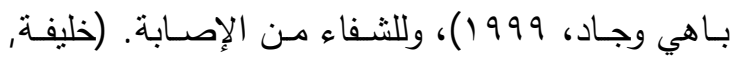
. ( r... T

وتكمن أهمية التصور العقلي في تنس الطاولة في استخدام اللاعب الإحسـاس البصري لمشـاهدة الكرة وحركات المنـافس كمـا يستعمل الإحسـاس الحركي من الإسن خـلال وعسي اللاعـب لجسـمه وهـو يتحـرك باتجاهـات مختلفة للإحساس بحركة الضرب أثناء ضرب الكرة. أما

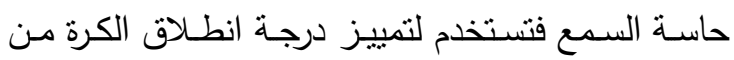
خـلد الصـوت النـاتج مـن قـوة ضـرب الكرة ويسـتخدم التصـور العقلي في التـدريب على الضـربات الخاصــة وذلك للارتقاء بمستوى الأداء والعمل على الإجـراءات

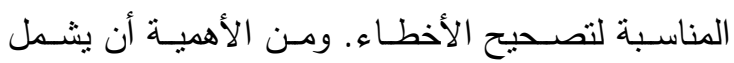

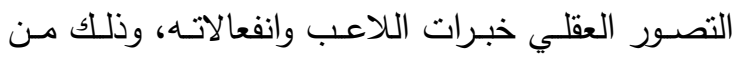

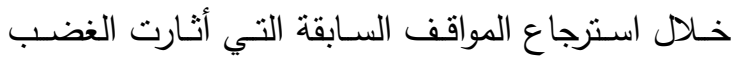
والقلق لديـه . فمن خـلا التصـور العقلي لتلك الأحداث
للمهارات النفسية المتقدمـة مثل : تركيز الانتبـاه وزيـادة الثقة بالنفس وانخفاض القلق.

يمثل الاسـترخاء أحـد الأبعـاد الأساسـية في

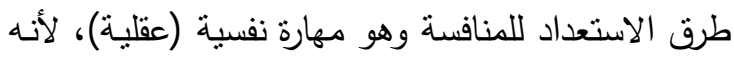
يسهم في مواجهة الضـوط المرتبطة بالمنافسـة ويسـاهم في خفض القلق والاستثارة غير المطلوبـة التي يمكن أن تتشـأ في مثنل هذه الظروف، ويعتبر الاسترخاء القاسم المشنرك في جميع برامج الإعداد النفسي ومدخلا أساسيا

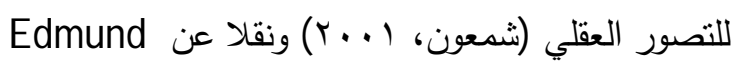
J acobson

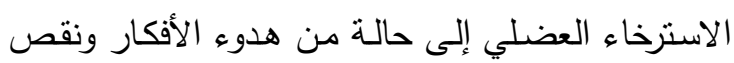
النشاط العاطفي (الانفعالي).

إن لعبة تتس الطاولة من الألعاب الفردية التي

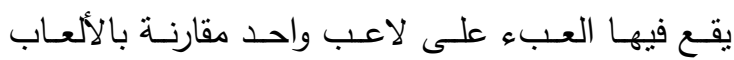
الجماعية.وتعتبر من الألعاب التي تعتمد على المهارات

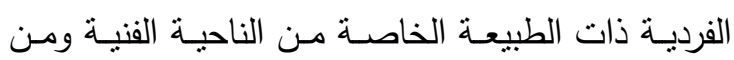
حيث طبيعة الملعب وصغر مساحته، وصغر حجم الكرة وسـرعتها وصــر مسـاحة المضـرب وأسـلوب السـبطرة عليها, والمنطقة التي تؤدى منها الضربات المختلفة للكرة

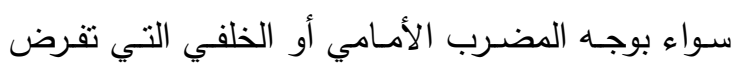

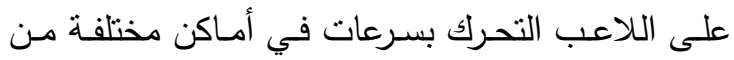
الطاولة، كمـا نجد أن مهارات اللعبـة تتمثل في إخراج انقباضـات عضلية سريعة في أقل زمن ممكن كما أن المشكلة الشائعة بين لاعبي تنس الطاولـة هي محاولـة قبض العضـلات عند زيادة قوة الضربة، مما يؤدي إلى لـ لهـي

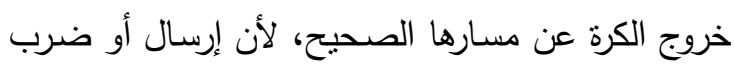

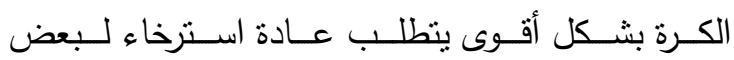
العضــلات الرئيسـة مقابـل العضــلات المســاندة بحيـث يمكن تحقيق أفضل تحكم وتوافق في أقل جهد. ويشير كل من شمعون والجمال(1997 1) بأن

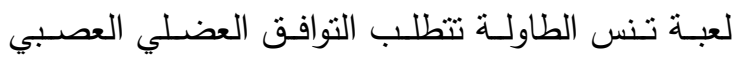

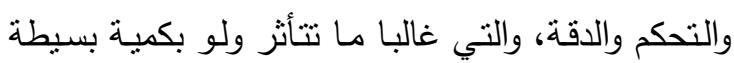

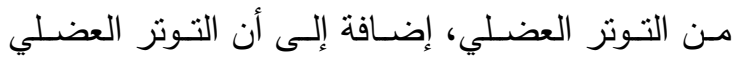


بطريقة سلبية وعدم التقـة بـالنفس وتشتنيت انتباهـه ممـا يؤدي إلى تدهور مستوى الأداء.

أمسا القـق فيعتبر أحـد المشكلات التي نواجـهـ

معظم اللاعبين وله العديد من الآثار السلبية ومنها:

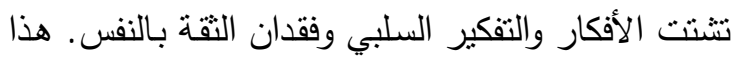
وقد يؤدي المستوى العالي من القلق إلى التأثنير السلبي

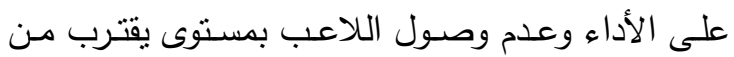
الحد الأقصى لقدراته، خاصـة في المنافسات أو المراحل الحرجـة، إضـافة إلىى جمـود الأداء وفقدانـه للانسـيابية

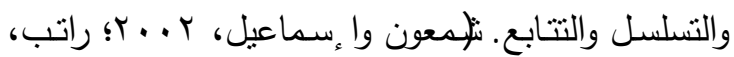

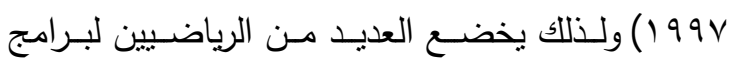

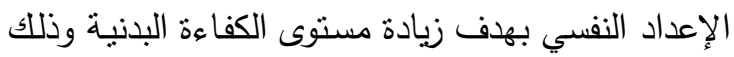
مـن خـلال زيـادة التقــة بـالنفس وزيـادة تركيـز الانتبـاه وبالتالي السيطرة على القلق والتحكم بضـغوط المنافسـة

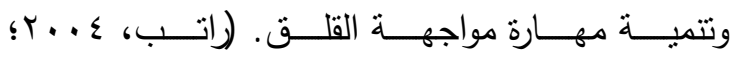
.(Straub,1996

إن القلق بمثل أحد المؤثرات الهامـة في لعبـة

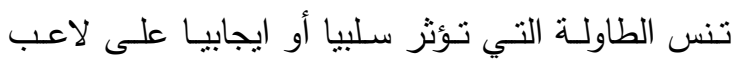
تنس الطاولة، لأنـه قد يزداد القلق في الأدوار النهائيسة

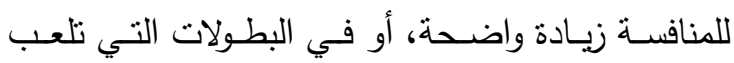
بنظام,و خروج المغلوب من أول مرة واحدة، مما يتطلب

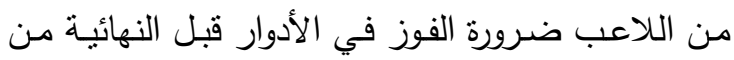

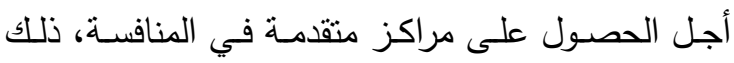

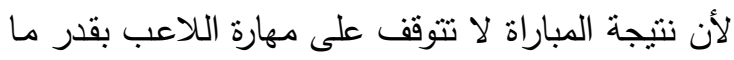
تتوقف على مستوى القلق الذي ينتابـه قبل وفي أثناء لتهاء

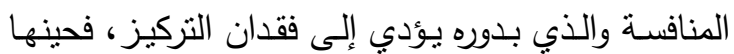
يبدأ اللاعب بتفسير الأعراض التي انتابته بطريقة سلبية مما تجعله يوجه تركيزه على الرموز غير المرتبطة بييئته

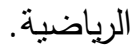

ويعتبر تركيز الانتبـاه مهارة نفسية (عقليـة)،

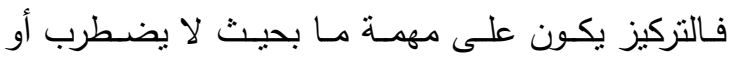

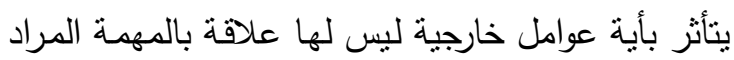

يسـهم التصـور العقلي في بنـاء الثقة، وذلك من خـله

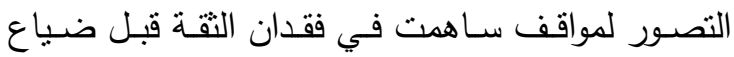
بعض النقاط، كما تكمن أهمية التصور العقلي في زيادة

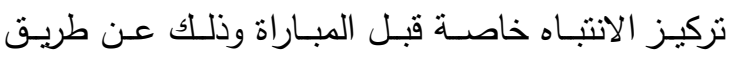
تصور المباراة, مع التركيز على الأبعاد المرتبطة بالبيئة

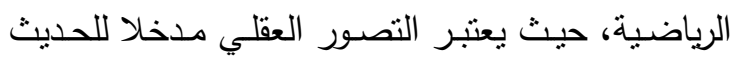

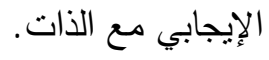

ويعتبر الحديث مع الذات أحد أساليب الإعداد

النفسي، وهو مهارة نفسية (عقلية) تساعد اللاعب على ولى

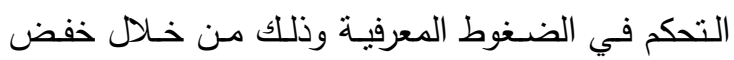
تأثنير الاستجابة للضغط العصبي وخفض مستوى القلق

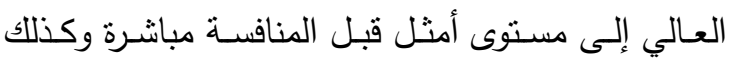
أثناء المنافسة وبعدها مما يؤدي إلى رفع مسنوى الأداء

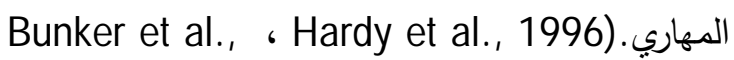

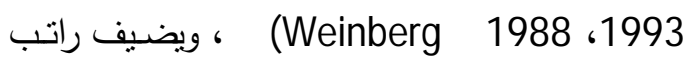

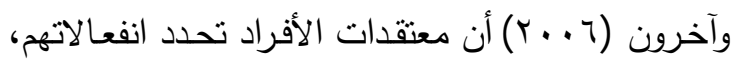
وتؤثز بقوة في سلوكهم، وعادة ما تتكون معتقداتهم نتيجة

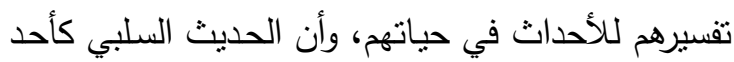

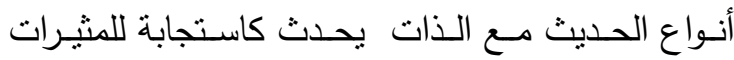
البيئية التي تتبعها الأفكار السلبية وبالتالي ترتفع درجة

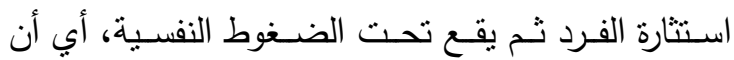
الأفكار السلبية تحدث قبل الاستتارة، وحتى يتم التحكم بالضغوط المعرفية (العقلية) فيجب عندها اكتشاف طرق الاف

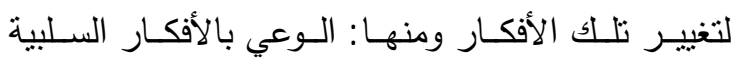
وا يقاف الأفكار والحديث الإيجابي مع الذات. إن لاعب تنس الطاولــة يحتـاج إلـى اكتسـاب

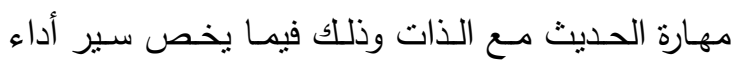
المهارات وسير المباراة وذلك في الفترات قبل وأثناء وبعد الأداء، وخاصة في اللحظات الهامة والمواقف الضاغطة والحرجة، مدا ينطلب من اللاعب تحديد عبارات ذاتيـة

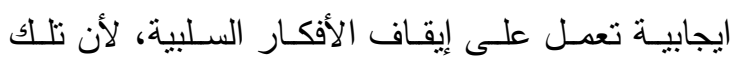

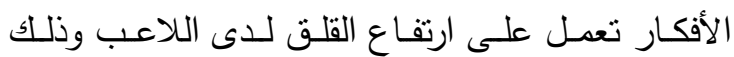

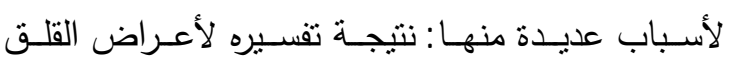




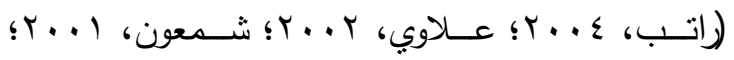

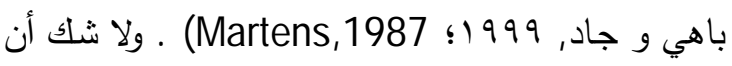

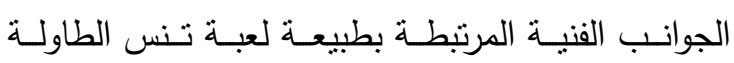

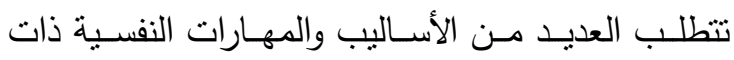

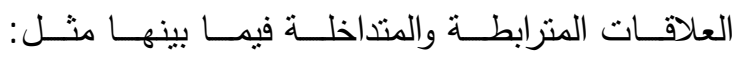
الاسترخاء، التصـور العقلي، الحديث مـع الذات وأثرهـا على مواجهة القلق وبنـاء الثقة بـالنفس وتركيز الانتباه وبالتالي أثزها على تحسن مستوى الأداء المهاري.

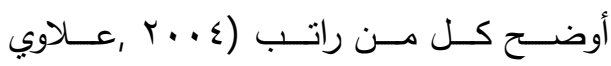

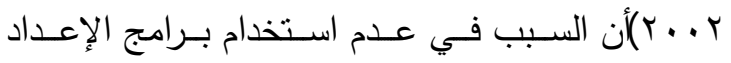

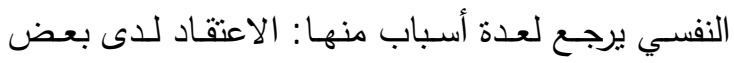

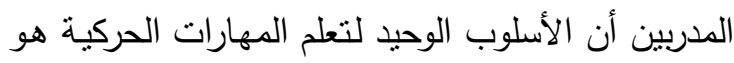
ساعات عديدة من التدريب البدني المتواصل والانتظام في الممارسة وتكرار الأداء للوصول إلى مرحلة الإتقان .

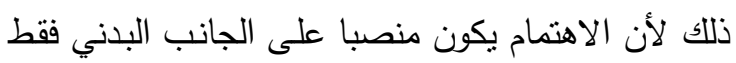

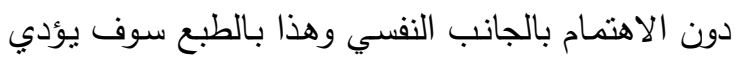

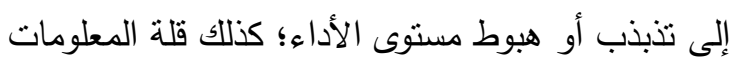

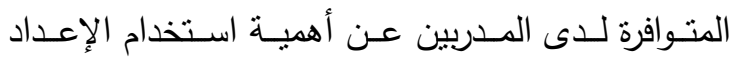
النفسي فهم لا يعرفون طرق وأساليب استخدامه وبالتالي

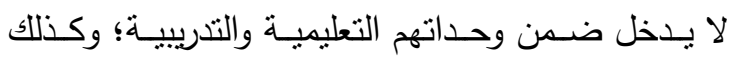

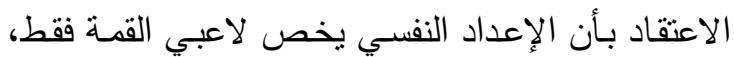

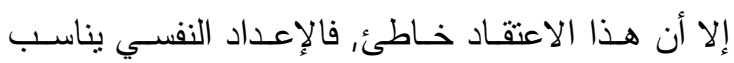
اللاعبين بـاختلاف مستوياتهم بمن فيهم الناشـئون وذوو المستويات العالية؛ إضافة إلى اعتقاد المدربين بأن إنفاق

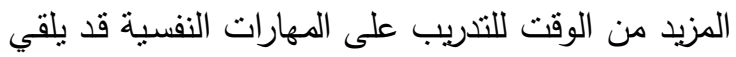
المزيد من الأعباء على اللاعب؛ ومن المفاهيم الخاطئة

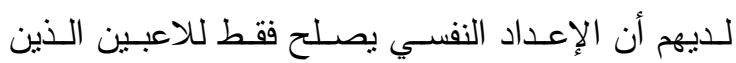

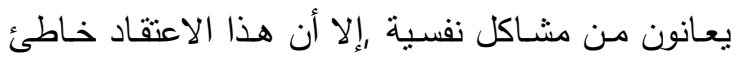

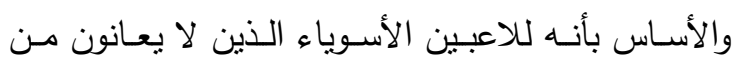

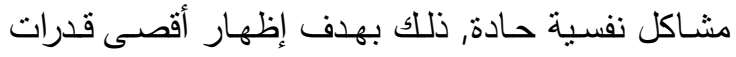

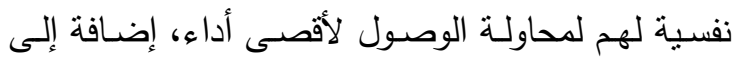

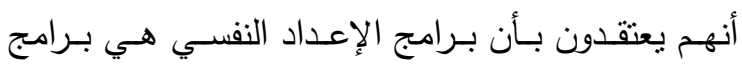

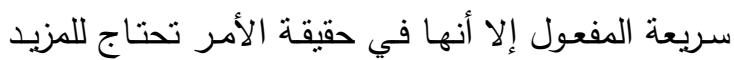
من التدريب المستمر مثل تدريب المهارات الحركية.
القيام بها ومـن هذه العواملـ : الضوضـاء التـي يطلقهـا

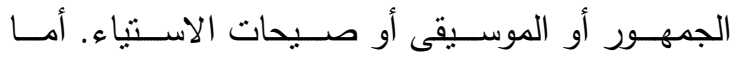

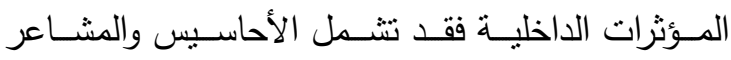
الجسدية التي تسبب تشويش الانتباه منل عبارة " أنا فعلا

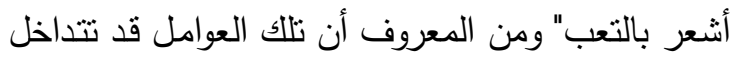
مع بعضها البعض، لأن كل حدث خارجي من شأنه أن أن

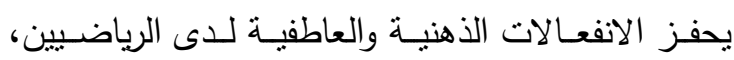
ولذلك يجب على المدربين تدريب رياضييهر على كيفية

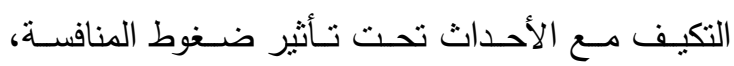
(Schmid \& Peper, 1993)

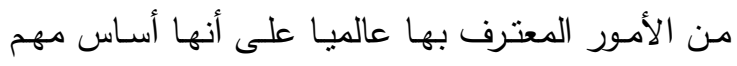

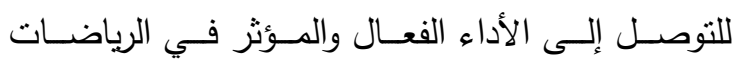

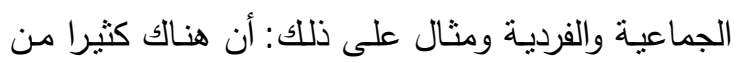

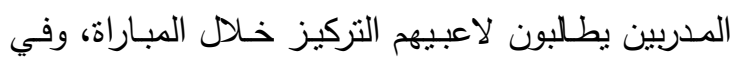

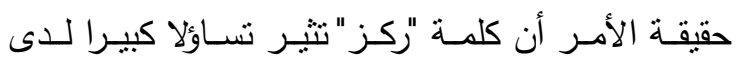

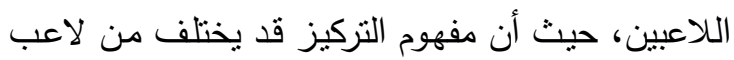
إلى آخر ، وقد لا تفهمه الغالبية العظمى من اللاعبين والمدربين (Nideffer, 1992)

ومن المتوقع وجـود علاقة سلبية بين القدرة

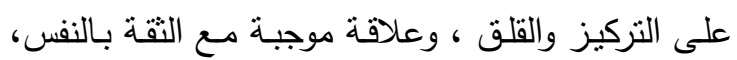

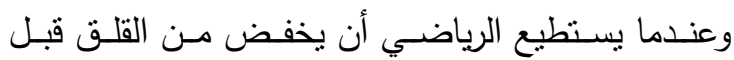

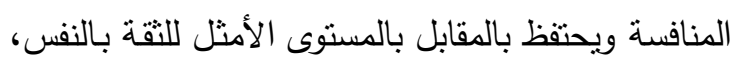

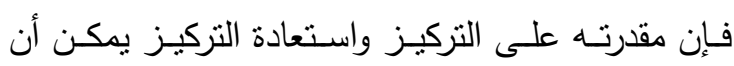
تزداد. (بدوي وراتب , . . . ب)، هذا ويتوقع وجود علاقة

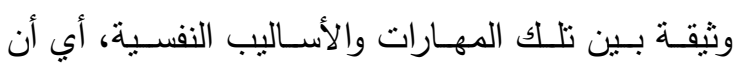

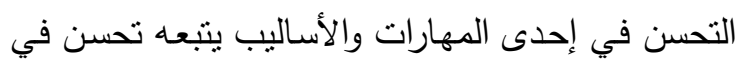

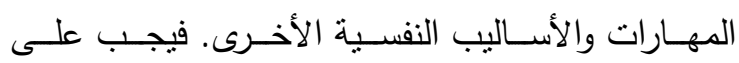
اللاعب أن يكون مسترخيا حتى يستطيع أداء التصسور

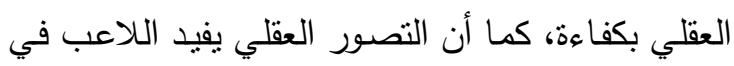

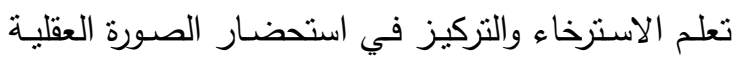

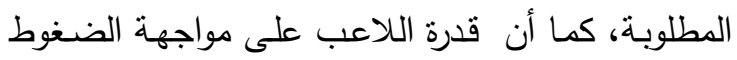

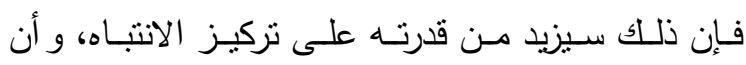

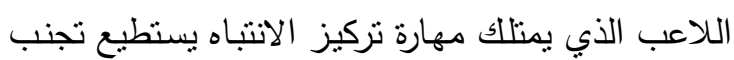
واءيقاف الأفكار السلبية الني تعتبر مصدرا للقلق السلبي. 


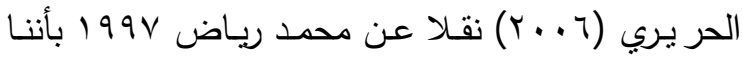
نتفاعل مع العالم الخارجي بواسطة تفسيرنا للإحساسـات

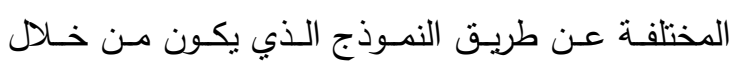

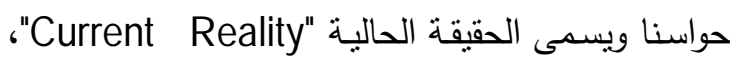
ولكن إذا استطعنا إضـافة مدخلات الحواس من خـلاص الوسـائل التكنولوجيـة (الحواسـيب)، لتمثيـل محبط آخـر

(Virtual Reality). يسمى الحقيقة الافتراضية لئبنه

أهداف الدراسة:

\section{تهدف هذه الدراسة إلى التعرف على:}

ا - أثنر أسـاليب الإعـداد النفسـي والمدعمــة بوسـائل

\section{تكنولوجيـة (Macromedia Flash) على العـى}

(الاسترخاء، التصـور العقلي، الحديث مـع الذات)

$$
\text { لدى ل الدبي تنس الطاولة. }
$$

r- أثر أسـاليب الإعداد النفسي (الاسترخاء، التصسور

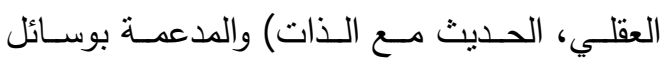
تكنولوجية على مواجهة حالة قلق المنافسة وتركيز

$$
\text { الانتباه لاى لاعبي تتس الطاولة. }
$$

ץ- أثزر أسـاليب الإعداد النفسي (الاسترخاء، التصـور

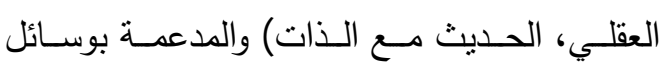
تكنولوجيـة على مسـتوى الأداء لـدى لاعبي تنس

$$
\text { الطاولة. }
$$

\section{فرضيات الدراسة:}

ا . . يوجـــ تـأثنير إيجـابي دال إحصــائيا للبرنـامج

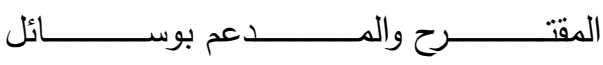

تكنولوجية(Macromedia Flash) على

(الاســترخاء, التصــور العقلـي والحـديث مـع

$$
\text { الذات) لدى لاعبي تتس الطاولة. }
$$

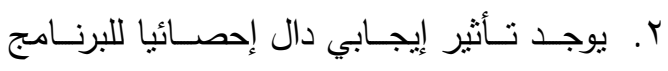

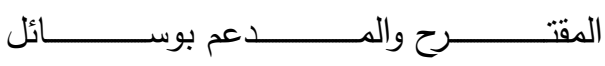

تكنولوجيـة(Macromedia Flash) على
ونتيجة لخبرة الباحثين المعرفية والتتافسية, فقد

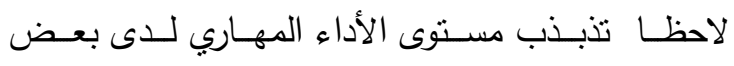

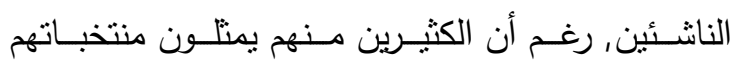
الوطنية, وأن هناك العديد من اللاعبين اللذين يمتلكون

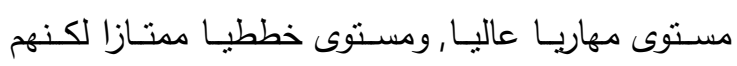

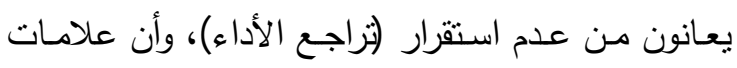
من القلق والتوتر والانفعال تظهر عليهح بشكل واضـح

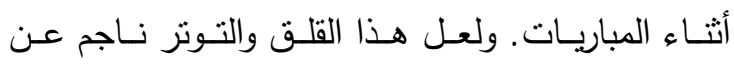

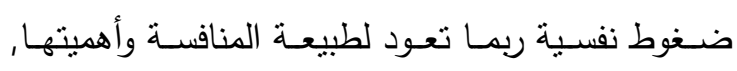

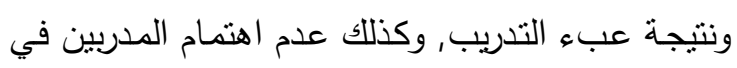

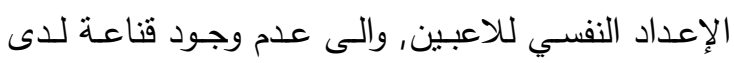

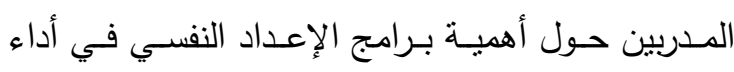

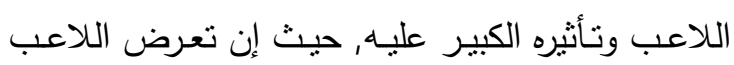

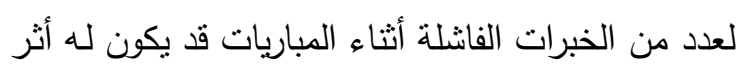

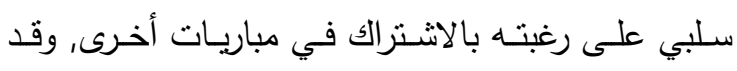

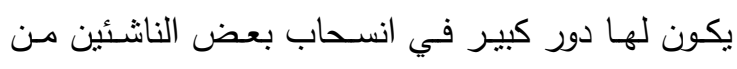

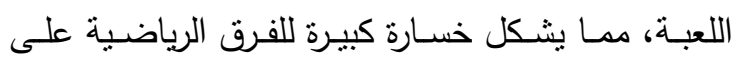

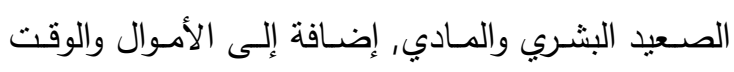
اللذين يهدران من أجل إعادة تأهيل فرق جديدة.

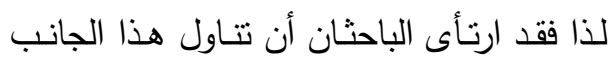
من الإعداد النفسي للناشئين؛ ذلك لأن خبراتهم السابقة تكون محدودة مما يسهل على المدرب أن يعيد تتكيل خبراتهم ومهاراتهم , وبما أن لعبة التنس الطاولة تحتاج

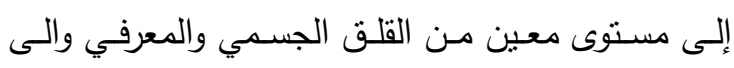

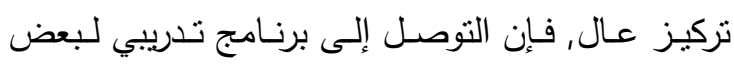

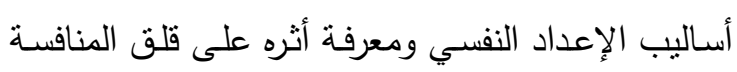
وتركيز الانتباه ومستوى الأداء سوف ينعكس إيجابا من خلال النطبيق الفعلي في المباريات ـ كما يرى الباحتنان

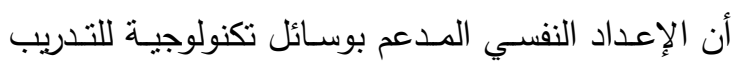
على المهارات الأساسية هو الأكثر فاعلية لأنه يسـاهم

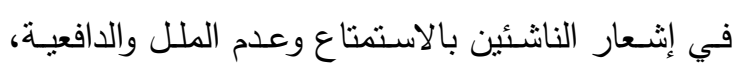

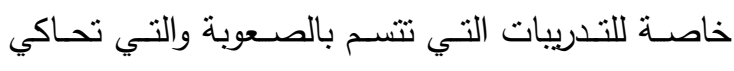

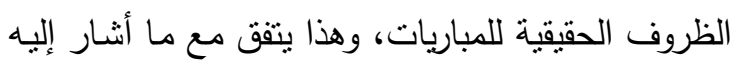


أماميـة ، رافعـة خلفيـة ) التي تتضـنها لعبـة تنس

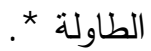

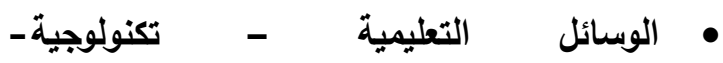
(Macromedia Flash)

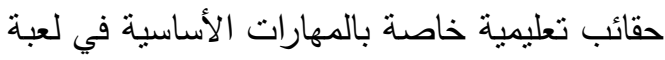
تتس الطاولة والتي تحاكي الظروف الحقيقية

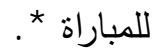

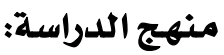

استخدم المنهج شبه التجريبي ذي المجموعـة

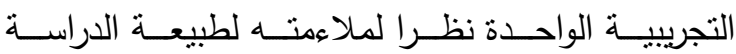
وأهدافها.

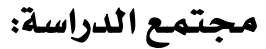

تكون مجتمع الدراسة من جميع لاعبي ولاعبات المنتخب الأردني لتتس الطاولة الناشئين للفئة

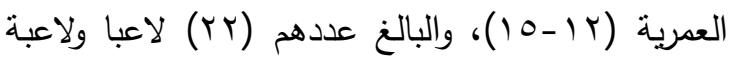

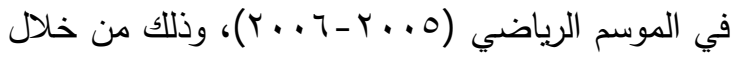

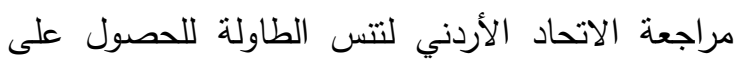
أسماء وعدد اللاعبين تبعا لكل نادي.

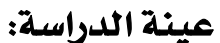

تم اختيار عينة الدراسة بالطريقة العمدية وذللك بناء على نتائج البطولة التي نظمت لأغراض هذه الدراسة وبالتعاون مع نادي عمان الرياضي، لجميع لاعبي ولاعبات المنتخب الأردني لتتس الطاولة الناشئين

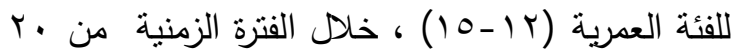

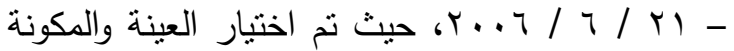
من خمسة لاعبين ولاعبتين بناء على نتائجهم التي كانت تقع في الربع الأدنى في اختبارات الدراسة وهي

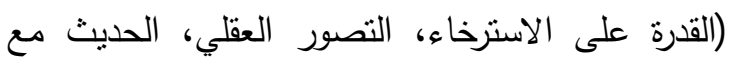
الذات، حالة قلق المنافسة، تركيز الانتباه، مستوى الأداء المهاري)، التي أجريت لهم خلال البطولة، وبذلك تكون الاناهن

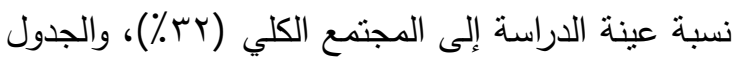

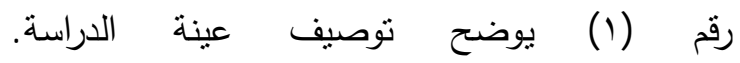

( حالـة قلـق المنافسـة وتركيـز الانتبـاه) لـدى لاعبي تتس الطاولة.

r. يوجـد تـأثير إيجـابي دال إحصــائيا للبرنــامج

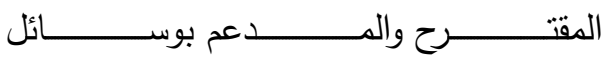
تكنولوجيـة(Macromedia Flash)على تحسين مستوى الأداء المهاري للدى لاعبـي

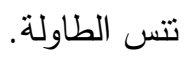

\section{مصطلحات الدراسة: تعريف إجرائي}

\section{Psychological أسـاليب الإعداد النفسيس} Preparation Methods تهذف إلى تجهيز اللاعب معرفيا وجسميا لتتمية مهاراته النفسية وذللك للتحكم بضغوط المنافسـة ؛

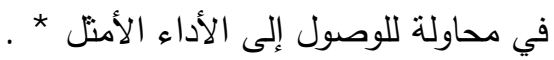

الاسترخاء Relaxation: مهارة نفسية (عقلية) ؛ وأسلوب يكتسب من خـلا التعلم والتدريب وهو مقدرة اللاعب على التحكم بجسـمه مـن حيث خفض التوتز والسبطرة على انفعالاته في المواقف * المرتبطة وغير المرتبطة في البيئة • الحـديث مــع الــات Self-Talk: مهارة نفسـية (عقلية ) وأسلوب يكتسب من خلال التعلم والتدريب , وهو مقدرة اللاعب على التحكم بمحتوى التفكير

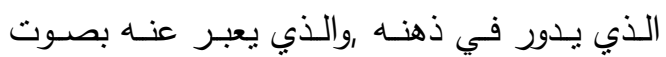

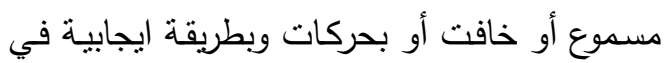
المواقف المرتبطة وغير المرتبطة في البيئة *.

Competitive State حالـة قلق المنافسة : : إدراك ذاتي انفعالي مؤقت يتميز بالخوف والتوتز تصـاحبه استثاره معرفيـة وجسمية ويزول بزوال المثير أو باستخدام أسـاليب الإعداد

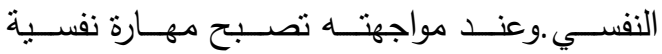

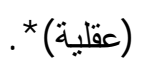

الأداء المهــاري : مسـتوى أداء اللاعـب للمهـارات

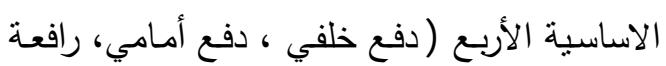


جدول رقم (1)

\begin{tabular}{|c|c|c|c|c|c|c|c|c|c|c|}
\hline \multicolumn{3}{|c|}{ 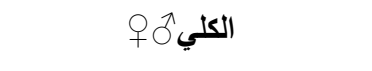 } & \multicolumn{7}{|c|}{ اللاعبون (ن=V) } & \multirow[t]{2}{*}{ متغير } \\
\hline 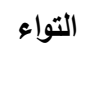 & الانحراف & متوسط & qV & $q_{1}$ & jo & $d \varepsilon$ & $\partial^{\top} r$ & $\partial r$ & ふ & \\
\hline $1.1 \leq$ & $1 . r)$ & IT.10 & ir & ir & 10 & ir & ir & IT & $1 \varepsilon$ & العمر الزمني (سنة) \\
\hline - . . & דז., & r.vA & $\varepsilon$ & $\varepsilon$ & r. & $\varepsilon$ & r.० & $\varepsilon$ & r.० & العمر التدريبي (سنة) \\
\hline
\end{tabular}

الانفعالية على قدرة تركيز الفرد لانتباهـه لفترات زمنيـة

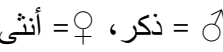

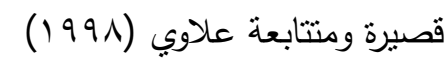

أدوات الدراسـة:

؛. مقيـاس حالـة قلـق المنافسـة (CSAI- 2)

Competitive State Anxiety

(علاوي، Inventory

•. أداة قياس الحديث مع الذات خلال المنافسة

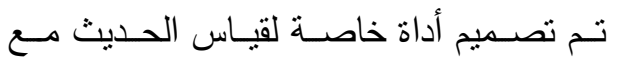

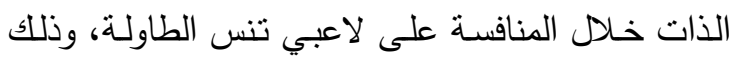

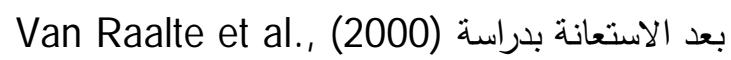

ج. أداة قياس مستوى الأداء المهاري .

صـممت هـــه الأداة لقيـاس مسـتوى الأداء

المهاري (المهارات الأساسية) في تنس الطاولـة خـلال المنافسة وهي: دفع أمامي Fore Hand Push ، دفع

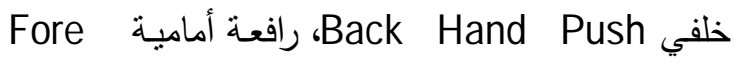
،Back Hand Drive رافعة خلفية، Hand Drive حيث تم تجزئـة كل مهارة من المهارات السـابقة إلى رعلى

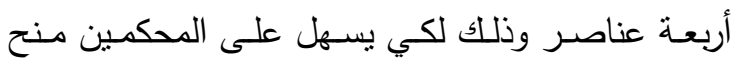
اللاعب حد أقصى (• (1) درجات موزعة على العناصر

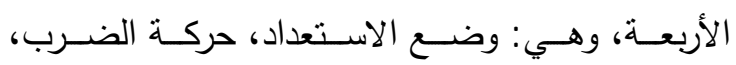

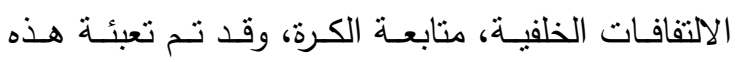

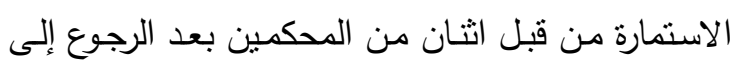

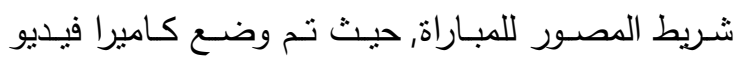
بزاويــة مناسـبة توضــح العناصـر المكونــة للمهــارات الأساسية من خلال اللعب ، وقد تم استخدام هذه الأداة
تم استخدام مجموعة من الأدوات لجمع بيانات

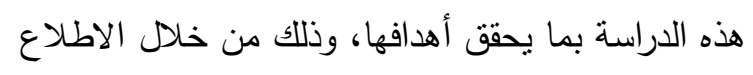
على البحوث والدراسات ذات العلاقة: أولا : الأدوات الخاصة بقياس المتغيرات النفسية: ا ـ مقيــاس القـــرة علـى الاســترخاء (ثـمعون Ability to Relax Scale ،( () 999 r. مقياس التصور العقلي في المجال الرياضي Mental Imagery Scale in Sport محمــ شـمعون وماجـدة إســماعيل ســنة

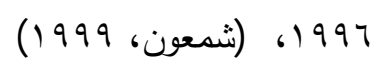
r. اختبار التركيز الملون للاعبي تنس الطاولة Colored Concentration

Test For Table Tennis Players

تم تصميم اختبار تركيز الانتباه الملون للعبـة

Mervat Colored تنس الطاولـة تحت عنوان Concentration test for table tennis d2 players ، والـــي اتبــع فكـرة وتعليمـات اختبـار لتركيز الانتباه الذي قام بتصميمه عالم النفس الألماني Brickenkamp(1978) تأثنير أنواع مختلفة من الأعباء أو الضـغوط البدنيـة أو

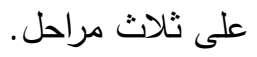


للبطولة، مع مراعاة نوفر نفس الظروف والتعليمات

للنطبيقين، ثم حساب معامل الارتباط بين نتائج النطبيق الأول ونتائج النطبيق الثاني لمقياس

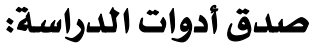
التصور العقلي ولمقياس القدرة على الاسترخاء،

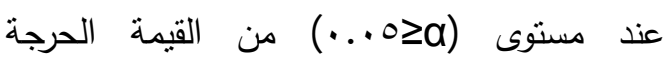
(الجدولية) البالغة AVA. . مما يعني ثنات مقياس التصور العقلي والقدرة على الاسترخاء وتركيز

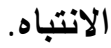

r - التحقق من الثبات بطريقة كرومباخ ألفا لأداة الدراسة الخاصة بقياس حالة قلق المنافسة وكانت قيم معامل الارتباط أعلى من القيمة الحرجة

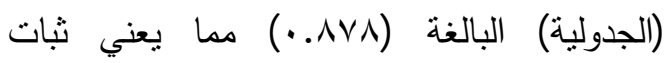

\section{مقياس حالة القلق المنافسة.} r -نظرا لأن أداة الدراسـة (الحديث مـع الذات) تحتـاج إلى تطبيق اثثين من المحكمين، فقد قام الباحثان بدراســة العلاقــة الارتباطيــة بــين نتــائج هـــنين

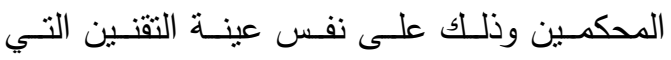

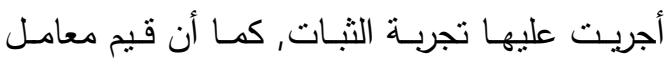
الارتباط كانت أعلى من القيمة الحرجة (الجدولية) البالغة AVA. . مما يشير إلى موضوعية المقيمين في تقييم الحديث مع الذات

؛ - للتأكد من مدى ثبات المحكمين في الأداء المهاري,

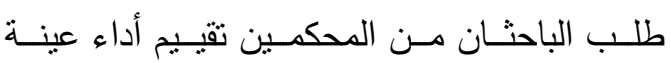
التقنيين وذلك من خـلال الرجوع إلى شريط الفيديو

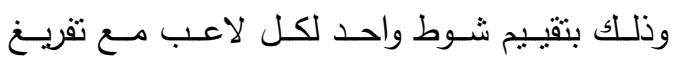
الـرجات على اسـتمارة استكثـاف الأداء المهـاري ولمـرتين متتــاليتين بفـارق زمنـي ثلاثــة أيسام بـين التطبيقين, وكانت النتائج تشير إلى ثبات كل مقيم

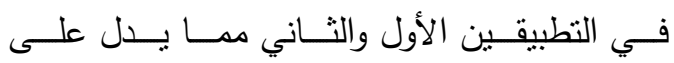

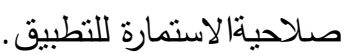

البرنامـج المقترح لدراسة بعض أساليب الإعداد النفسي:

تـم تصــميم البرنـامج التـدريبي بعـد الرجـوع إلـى المصــادر والدراســات العلميــة ذات العلاقــة بالإعــــاد

ثانيـا: بالنسـبة لأداة قيـاس الأداء المهـاري وأداة قيـاس الحديث مع الذات اعتمد صدق المحكمين وقد تبين

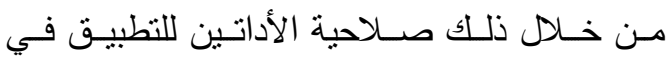
الدراسة الحالية. ثالثـا : بالنسبة لأداة قبـاس تركيز الانتبـاه الملـون لدى

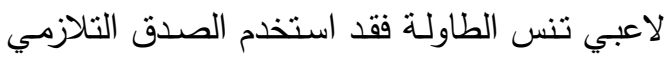

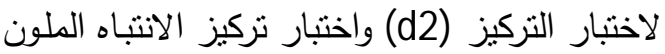

$$
\text { لدى لاعبي تتس الطاولة. }
$$

\section{ثبات أدوات الدراسة:}

نظرا لتعدد أدوات الدراسـة فقد تحقق الباحثان من ثبات أدوات الدراسة على النحو التالي:

ا - النطبيق واءعادة التطبيق Test Retest وذلك لأدوات الدراسة التالية: (القدرة على الاسترخاء، التصور العقلي، تركيز الانتباه)، حيث نم تطبيق

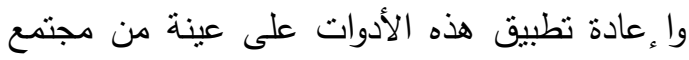
الدراسة وخارج نطاق العينة الأصلية، والمكونة من لهن العن (0 ) لاعبين، المشاركين في البطولة التي نظمها

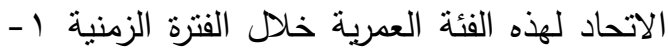
T /ه / T . . T، حيث نم التطبيق الأول في اليوم الأول للبطولة والنطبيق الثاني في اليوم الأخير 


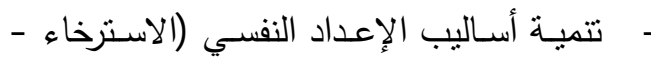

$$
\text { التصور العقلي - الحديث مع الذات). }
$$

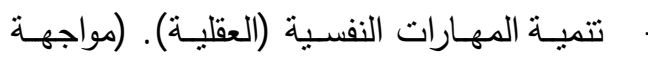

حالة قلق المنافسة، تركيز الانتباه).

- تحسين مستوى الأداء لدى لاعب تتس الطاولة

في المهارات الأربع (دفع خلفي، رافعة أمامية,

$$
\text { رافعة خلفية, دفع أمامي). }
$$

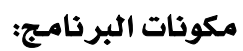

يشتمل البرنامج المقترح على مجموعة من الأبعاد وهي:

1 - الاســـترخاء العضــــلي (التعـــــبـي، التخيلــــي

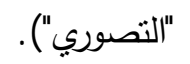

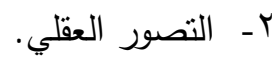

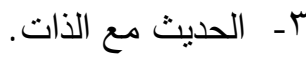

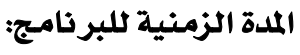

تم تحديد مدة البرنامج النفسي المقترح بـ (r ا )

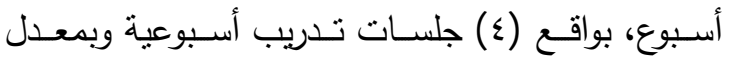

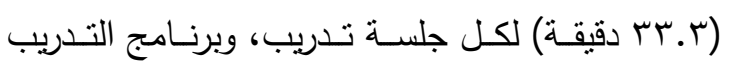

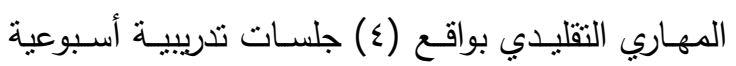

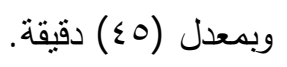

برنامج Macromedia Flash: برنامج نم تصميمه على صورة الحقائب التعليمية حيث تم العمل على إدراج قوائم وأزرار بسيطة غير معقدة التركيب في تصميمها

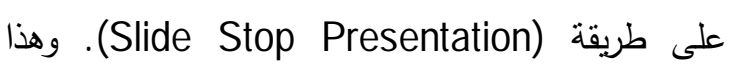
يعني شرائح متحركة تفصل بينها أزرار حتى تعود

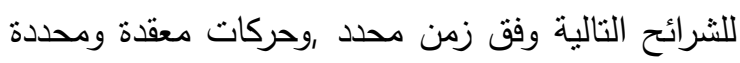
التصميم ، حيث تم استخدام برامج التصميم للحقيبة

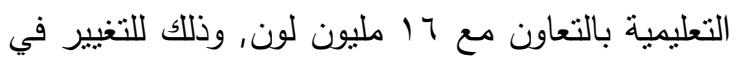

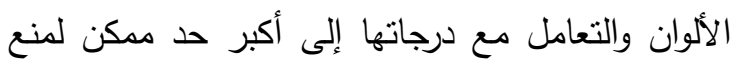
حدوث عين التصميم لدى اللاعب وهي (أن تتعود العين

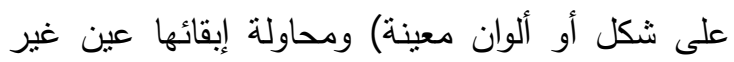

النفسي للاعبين، وبعد التوصل إلى البرنـامج بصـورته الأولية تم عرضه على مجموعة من المحكمين من ذوي الخبرة والكفاءة ومن أصحاب الاختصاص، وذلك بهدف

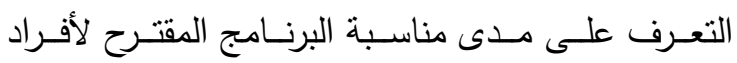

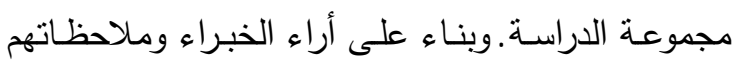
أجريـت بعض التعـيلات على البرنـامج المقترح منتل : (ذكر أمتلة على لاعبين عالميين, الإكثار من الجلسات الفردية, الاهتمام بالواجبات المنزلية).

\section{أـ تم وضع البرنامج ضمن المحددات التالية:}

التـدرج بالأسـاليب النفسـية التـي

تزيد من فاعلية المهارات النفسية والأداء من خلال فترة تطبيق البرنامج. ا ـ ـ مراعاة الفروق الفردية. ץ. الاستمرارية في التدريب.

r. عدم التسرع في الانتقال من مرحلة إلى أخرى.

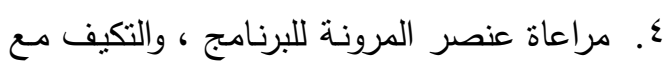
الظروف الطارئة ، ووضـع الحلول البديلة التي تضمن تحقيق الأهداف.

ْ. مراعـاة العوامـل الاجتماعيـة وظـروف الحيـاة

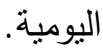

7 7. أن يوضـع في الاعتبـار الأدوات والإمكانـات

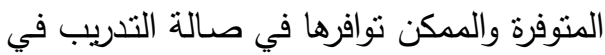

$$
\text { مسرح وقاعة مدارس النظم الحديثة . }
$$

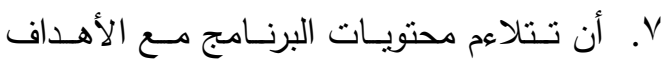

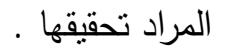

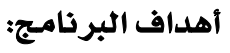

يعدف البرنامج المقترح لبعض أساليب الإعداد

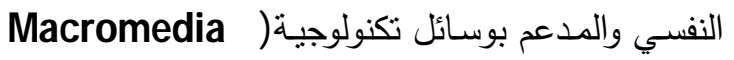

Flash 
- ت تحقيق حالـة من الاسترخاء العميق، والتحكم في

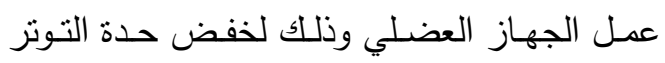
والقلق في فترات زمنية أقصر .

خطوات التنفيذ:

1- - يناقش المدرب اللاعبين بعد الاسترخاء (أهميته، متى يستخدم، أنواعه، العضلات العاملة). r- تعليم اللاعبين الاسترخاء التقدمي (1 (1 مجموعـة عضلية ثم تختصر إلى سبع مجموعات، ثم أربع مجموعات عضلية، ثم مجموعة عضلية واحدة مع

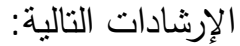

اختيار مكان مريح ويراعى أن تكون (الإضـاءة خافتة، موسيقى هادئة، موسيقى صاخبة) . الرقود على الظهر على بسـاط مفروش على

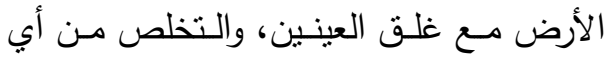
عوائق، والامتداد الكامل للجسم، وتجنب تقاطع

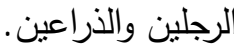

عنــما يـؤدى الاسـترخاء لمجموعـة عضـلية، يراعـى عـدم تحريــك هـــه المجموعـة مـن

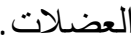

يـؤدي اللاعـب مجموعـة مـن الانقباضــات العضلية تتسم بالثــدة ثم الثبـات لفترة خمس لفس لفس ثوان للعضلات الكبيرة، وثلاثلث ثوان للعضـات الصـغيرة خاصـة فـي الوجـه، يعقبهـا الرجـوع لحالة الاسترخاء لمدة • ب ثانية.

تكرار التمرين مرتين لكل مجموعة عضلية. عند التخلص مـن تـوتز الانقبـاض العضـلي، يجب التخلص منـه تمامـا وذلك للتميز بين

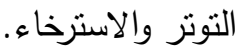
براعى الوعي بطريقـة التنفس، حيث الثـهيق

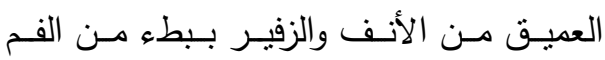
باعتبار أن ذلك نوع من الاسترخاء.
مدركة لحيثيات التصميم، كما زادت قابلية البرنامج

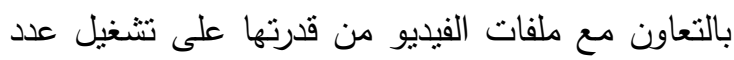
قياسي منها (9) ملفات في بعض الشرائح , وهذا أناح الفرصة لتعدد الخيارات لدى اللاعب في حقيبة الاختيار , لئل

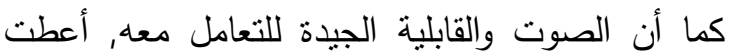
الفرصة لإدراج أصوات من ضمن بيئة اللاعب, والتحكم بعدد مرات الإعادة حيث أن درجة الصوت تعطي نتيجة فعالة في نقل اللاعب إلى مرحلة اللعب النتبيهي"محاكاة . (Simulating Game) "

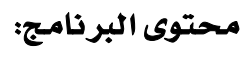

البعـــ الأول: الاســترخاء العضــلي Relaxation

Muscular

وهو البعد الذي يحتوي على نوعين وهــا : الاسترخاء التعاقبي ، والاسترخاء التخيلي (التصوري).

أولا: الاســـترخاء العضـــلي ( التعـــاقبي )

\section{Progressive Relaxation Training}

يمثل الاسترخاء العضلي أحد الأبعاد التمهيدية

الهامسة في برنـامج الإعـداد النفسي وهـو البعـد الـذي الذي يتضمن العمل البدني مـع العضـلات المختلفة، وقد تم الِم استخدام طريقة التدريب الاسترخاء التعاقبي، حيث يقوم اللاعب بأداء التوتر والاسترخاء المتتابع لـ 17 مجموعة عضلية، ثم تختصر إلى سبع مجموعات عضلية، في

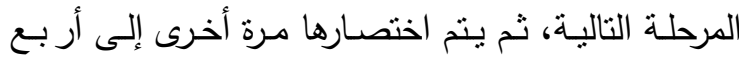

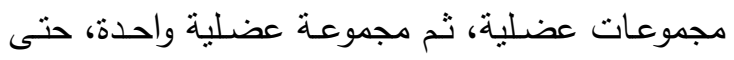
ينتم التخلص من التوتر لتلك المجموعـة العضلية عند الرغبـة في الاسترخاء ـ لتتفيذ هذا البعد والتي تتضـمن

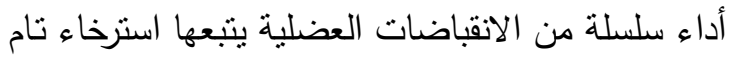
مـع الانتقال من مجموعـة عضلية إلى أخرى حتى ينت الاسترخاء في جميع المجموعات العضلية.

الهدف: - - تعليم اللاعبين التمبيز بين التوتز والاسترخاء. - التحكم بزيادة التوتر بتقديم مواقف تتسم بالتوتز . 
الهدف:

تعليم ومساعدة اللاعب الوصول إلى الاسترخاء التخيلي

(التصوري) وذلك لتخفيف الضغط والقلق وصفاء العقل

خطوات التنفيذ:

ا . يوضـح المـدرب للاعـب بعـد الاســرخاء التخيلي

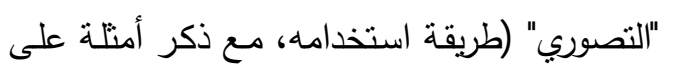

$$
\text { لاعبين عالمين) . }
$$

ץ. بعـد الوصــول إلـى درجــة الاســرخاء العضــلي

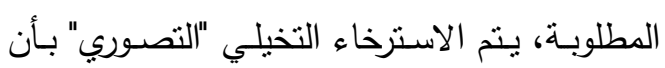

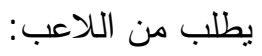

هالاسـترخاء التــام (الثـــيق العميـق، الزفيـر

$$
\text { البطي ء). }
$$

اتـرك التـوتز يخـرج مـن عضــلات جسـمك، الشهيق العميق، والزفير البطيء.

تخيل نفسك في المكان الهادئ ، المحبب إليك

$$
\text { ، وليس مجرد صورة . }
$$

$$
\text { الاستماع للأصوات، اسنتشاق الهواء . }
$$

•ممارسـة الاسـترخاء التخيلي "التصـوري" دون

إرثــادات خارجيـة حتـى يسـتطيع اللاعـبـ

استحضـار الصـورة الذهنيـة بسـرعة ويشـعروا

بالاسترخاء المرتبط بها .

الاستتمرار في الممارسـة خـلال الحيـاة اليوميـة

عند مواجهـة الضـغوط البسيطة والتدرج عند

مواجهة الضغوط الأكثر صسوبة في المواقف

الرياضية منل المنافسات .

• مارسـة الاسـترخاء التخيلي "التصـوري" بعـد

تتمية التصور العقلي متعدد الأبعاد .

وقد استغرق هذا البعد (rq) وحدة تدربييـة بزمن قدره

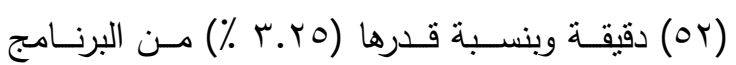

التركيز على مشـاعر التوتر والاسـرخاء في

الجسم.

تكـرار كلمـة اسـترخاء لكل مـرة يؤخذ الثــيق منها، لبدء الاستجابة للاسترخاء.

النهوض مـن وضـع الاسـترخاء تـدريجيا وذلك عـن طريـق اهتزاز أمشـاط القـدمين وأمشـاط الهـ اليـدين، تحريـك القـدمين واليـدين، فتح العـين بـبطء، تحربــك المـرفقين، تحربــك الـركبتين، الجلـوس بـبطء، الجلـوس علـى الـركبتين، ثـم الوقـوف وتمرينـات امتـداد ومطاطيـة عضـلة

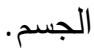
ب - - واجبات منزلية.

مثـال :"انقبـاض أصـابع اليـد والسـاعد اليمنـى" انقباضهما بشدة كلما أمكن مـ أخذ الثـهيق العميق من الأنف، كرر كلمة استرخاء، احتفظ بالتوتز لمدة خمس ثـوان، لاحـظ التـوتز غيـر المـريح فـي يـدك وسـاعدك

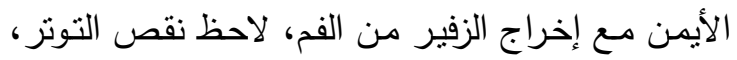

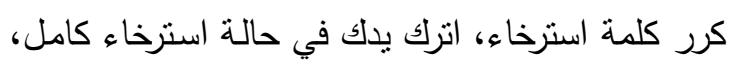
لاحظ كيف أن التوتر وعدم الراحة الذي كنت نشعر بـه والاسـترخاء الذي تشـعر بـه الآن، ركز على مثـاعر الاسنزخاء لبدك اليمنى لمدة ( • ب) ثانية.

وقد اسـتمر هذا البعـد (rV) وحدة تدريبيـة بـزمن قدره

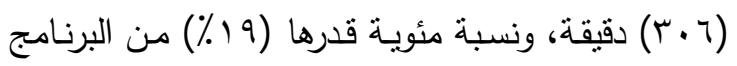

Imagery ثانيا : الاسترخاء التخيلي (التصسوري)

\section{Relaxation}

يتم الاسترخاء التخيلي (التصوري) بأن بطلب

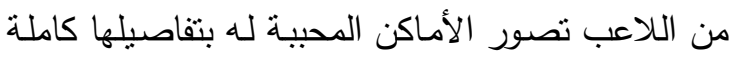

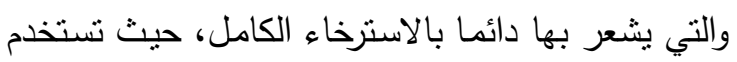

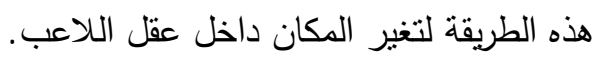


مثال : "افتح عينيـك تمعن بالأشـياء الموجـودة حولكك،

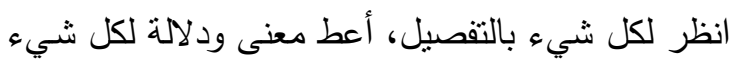

- يقـوم اللاعـب بــأداء تـــريبات لتتميــة التصــور

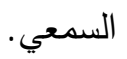

مثــال( (1) : "أغلــق العينـين، وأحســن الســمع لثــريط التسجيل، ما نوع الأصـوات المختلفة التي تستمع إليها؟

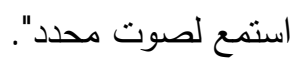

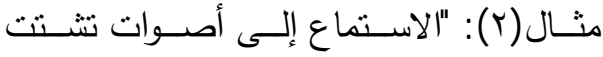

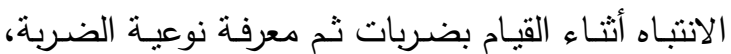
تصور أن ذلك الصوت المشتت يسري داخل العضلات يمد الجسم بالطاقة ويؤدي إلى أن تكون الضربات أكثر

- يقوم اللاعب بأداء تدريبات لتتمبة الحس الحركي.

مثــال : "اسـتمر فـي إغـلاق عينيــك، استحضــر الأحاسـيس والمشـاعر المرتبطــة بجســك وتركيـز

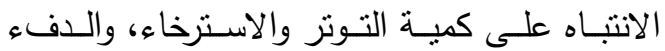
والوودة على جميع أجزاء الجسم المختلفة، الرأس، البهاء

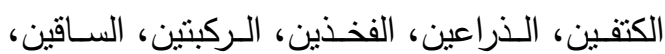

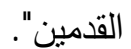
- يقوم اللاعـب بـأداء تـدريبات لتتميــة الإحسـاس

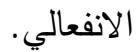

مثنال : "مـن خـلال المهارات الأساسية في تنس

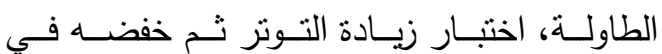

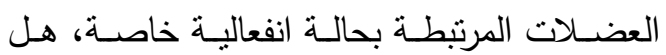

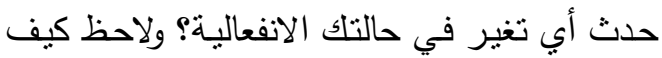
ذللك يؤثر على مختلف الضربات" . مبعد كل عمليـة تصـور عقلي يؤخذ الثــيق

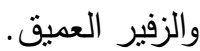

\section{البعد الثاني: التصور العقلي Mental Imagery}

يعتبر هذا البعد من الأبعاد الهامة الذي يعكس

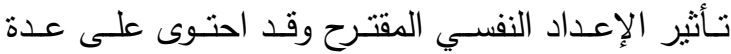

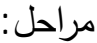

المرحلة الأولى: تتمية الوعي بالحواس (الرؤية، السمع، الإحساس الحركي، تصور الحالة الانفعالية).

المرحلة الثانية: التصور العقلي لتتمية وضوح

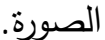

المرحلة الثالثة: التصسور العقلي لزيادة التحكم

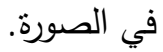
الهدف:

تحسين درجة ونقاء ووضوح الصورة العقلية مـع

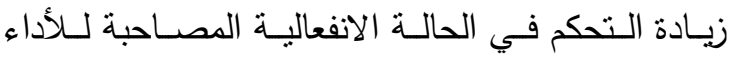
وتتميـة الثـعور بـالوعي الحسي ومحاولـة الارتقاء بهذه الأبعاد بطريقة متكاملة حتى يمكن التقام بعملية التصور العقلي الخاص بالمهارات قيد الدراسة في تتس الطاولة. وفي ما يلي توضيح للمراحل الثلاث السابقة:

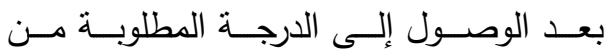
الاسـترخاء العضـلـي والاسـترخاء التخبلـي (التصــوري) يكون قد تم الوصسول إلى مكان الحجرة العقلية التي يتت فيها إجراءات تتفيذ هذه المراحل . المرحلة الأولى : تنمية الوعي بالحواس الهدف: - - الهد

$$
\text { خطواسـ أثناء الأداء الرياضين مقدرة اللاعـب على تتميـة الـوعي }
$$

- يقـوم اللاعـب بـأداء تــدريبات لتتميـة التصــور

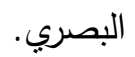


لألعـاب مختلفـة (مضـرب تـنس طاولـة ذو الوجـهـ

المرحلة الثانية: تنمية وضوح الصورة

الأسود) -أحذية رياضية لألعاب مختلفة.

الهدف:

تدريبات :(نرائح · ( -7 (1).

صور متحركة : (تتطيط الكرة بالوجهـ الأمسامي) (تنطيط الكرة بالوجه الخلفي) - (تتطيط الكرة بالوجها الأمامي والخلفي) - صور ثابتة للمهارات الأساسية الأربع: (دفع خلفي بالوجه الأسود) - الرافعة أمامية

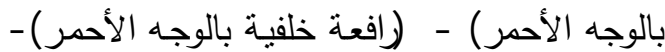

$$
\text { (دفع أمامي بالوجه الأسود) . }
$$

صـور متحركـة للمهارات الأساسية الأربعـة: (دفع

خلفي) - (رافعـة أماميـة) - (رافعـة خلفيـة) - (دفـع

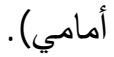

تم تكرار هذه التدريبات على أريع مراحل وتتكون من عشرين صورة ثابتة ومتحركة:

المرحلة الأولى: تنتمر بمتوسط زمني (1 . . ث ) بدون ضوضاء.

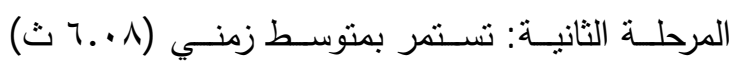

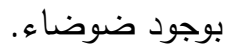

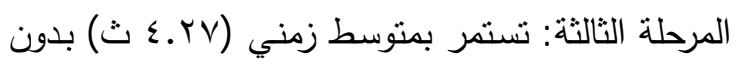
ضوضاء.

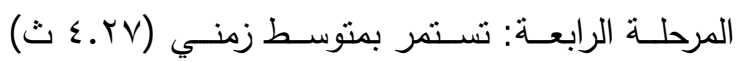
بوجود ضوضاء.

- في جميع المراحل السـابقة ينت تغيير أمساكن الصـور المطلوب النزكيز عليها واستحضارها .

- قبـل وبعـد كل عمليـة تصـور عقلـي يؤخذ الثـــيق والزفير العميقان . قبل عملية تركيز الانتباه يؤخذ الثهيق يونيق

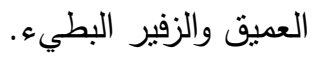

• تم عمل محك لتحديد الفترة الزمنية المناسبة للتركيز

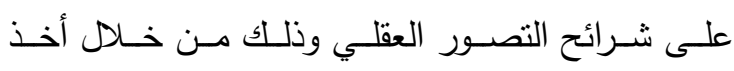

تتمية وضوح الصورة العقلية من خلال سلسلة من تمرينات تتمل الحواس الهامة.

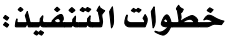

يقوم اللاعبب بـأداء تـدريبات التصـور العقلِي (وضـوح

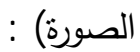

أ. تدريبات بعبارات شفهية، فبعد عملية التصور يقوم اللاعب بالإجابة على دفتر خاص بوضوح الصورة مثال: "ضـع نفسك في المكـان المـألوف لـايك والذـي تتدرب فيه عادة كصالة اللعب، تصور أنه لا يوجد أحد سوإك، حاول الوقوف في نقطة من هذا المكان بحيث

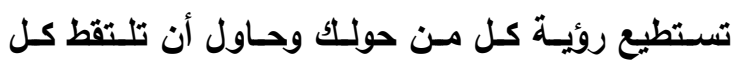
التفاصيل في هذا المكان، والآن تصور نفسك في هذا المكان ولكن في حضـور عدد كبير مـن المتفرجين، وتصور أنتك سوف تثترك في المنافسة في هذا المكان

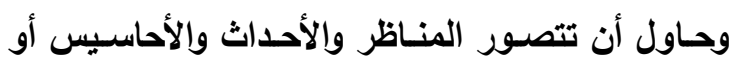
المشـاعر في حالـة اشتراكك في منافسـة أمسام هؤلاء المتفرجين وفي نفس هذا المكان المألوف لديك". ب. تدريبات مرئية بواسطة شاشة عرض، وذلك بعد أن

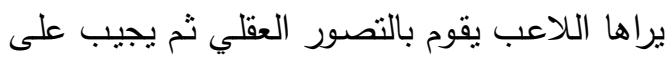

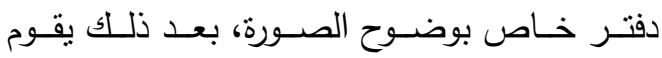
بالتركيز على ما تم تصوره من عدة خيارات عديدة

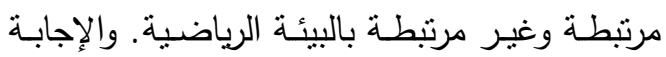
على دفتز خاص بتركيز الانتباه.

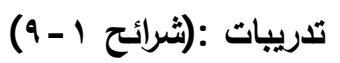
ألكوان متسلسـلة - مصـابيح إنـارة كرات متحركـة

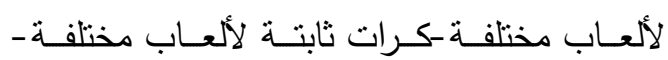

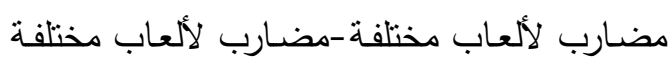

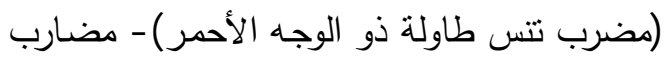




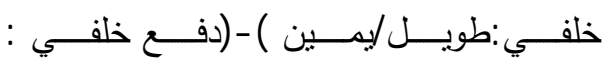

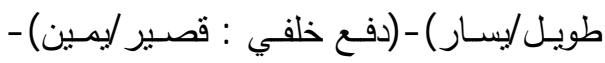

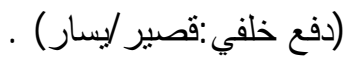

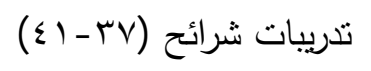

صـور منحركـة :(حركـات خاطئسة) -(رميـات ثنائية : رافعـة أماميـة لافعـة خلفيـة) - (رميات ثنائيسة : دفع خلفي ادافع أمـامي) - (رميـات ثنائيسة : رافعـة أماميـة/لدفع خلفي) -(رميـات الفيات ثنائية : رافعة خلفية/لدفع خلفي).

تم تكرار هذه التدريبات على أريع مراحل متكررة

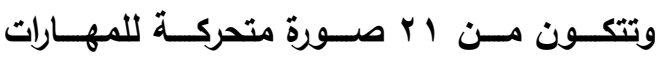
الأساسية الأربعة بتنس الطاولة:

المرحلـة الأولى : نستمر بمتوسط زمني ( T.0 ث) بدون ضوضاء.

المرحلة الثانية: تستمر بمتوسط زمني (r.0 ( ث ث) بوجود ضوضاء.

المرحلة الثالثة: تستمر بمتوسط زمني (. ثاث) بدون ضوضاء.

المرحلة الرابعة : نستمر بمتوسط زمني (. ثاث) بوجود ضوضاء .

- في جميع المراحل السابقة ينم تغيير أماكن الصور

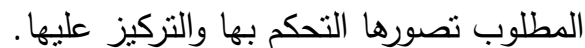

ب. تـــريبات بعبـارات شـفهية، ويعد عمليـة الـتحكم بالصورة يقوم اللاعب بالإجابة على دفتر خاص بتحكم الصورة.

مثال( (1): "تصور نفسك تلعب مع منافس قوي يسبب للك بعض المشكلات، حيث أصبحت النتيجة الصفر ، وفي

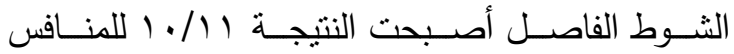
تصـور نفسـك تـؤدي المهـارة بالثـكل الصـيح كنقطـة

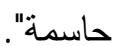

المتوسط الحسبابي لثلاثــة قياسـات مـن عينـة الثبـات باختبار تركيز الانتباه الملون لدى لاعبي تنس الطاولة وهي: (مرتفع متوسط -منخفض) .

المرحلة الثالثة: تنمية التحكم بالصورة

الهدف:

تتمية القدرة على التحكم الإرادي للتصور العقلي للارتقاء بمستوى الأداء للمهارات قيد البحث.

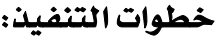

يقوم اللاعب بأداء تدريبات التصـور العقلي

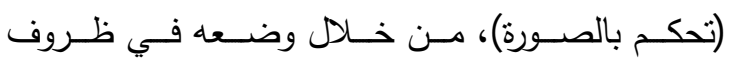

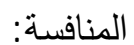

أ. تدريبات مرئية بواسطة شاشة عرض ، حيث يقوم اللاعب بعملية التصور والتحكم بالصورة المطلو بـة برابة

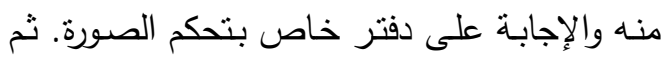
يطلب مـن اللاعب التزكيز على الصـورة المـراد

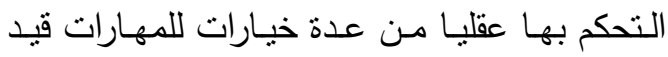
الدراســة ثم الإجابـة على دفتـر الخـاص بتركيـز

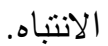

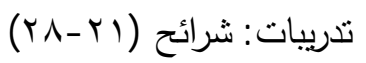

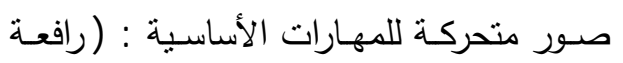

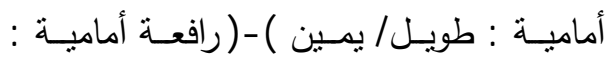

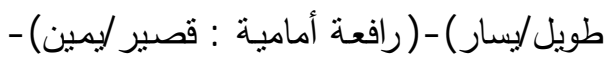

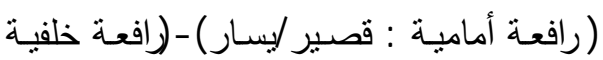

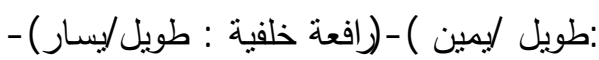

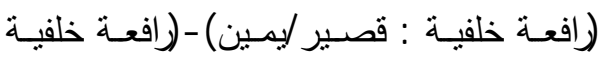

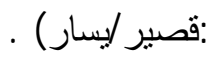

$$
\text { تدريبات شرائح (9 - بـr) }
$$

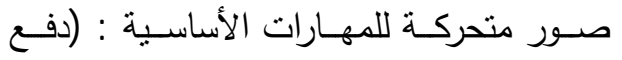

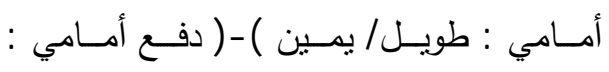

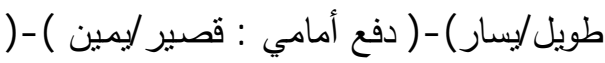

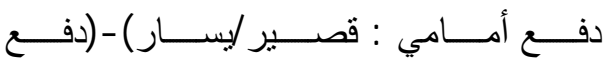


فيسه هذه الأفكار ، راجـع تسـيلك للتقـارير السـلبية

واكتب أي استخلاص تستطيع التوصل إليها)

تعليم اللاعبين كيفية إيقاف الأفكار ، حيث يتطلب هذا الأسلوب تشجيع اللاعبين على معرفة أنماطهم للتفكير ثم إجراء الخطوات التالية: تعلم التصور العقلي بفاعلية وكفاءة.

تحديد المواقف التي تتضدن الأفكار السلبية. تحديد الأفكار السلبية النوعية. تحديد (رمز أو إثـارة أو كلمة) محددة كمثير للنتبيه بإيقاف الأفكار السلبية. اقتــراح قائمــة بالتقــارير أو العبـارات الذاتيــة الواقعيـة الإيجابيـة تسـتخدم كبـديل للأفكـار الإيجابية.

واجبات منزلية

عندما تبدأ تعليم عملية إيقاف الأفكار ، فإن اللاعبين يجب أن يستخدموا التصور العقلي لنطوير هذا الأسلوب

$$
\text { أولا، ثم الممار سة في الموقف الفعلي. }
$$

وقد اسـتمر هذا البعد (• (1) وحدات تدريبيـة

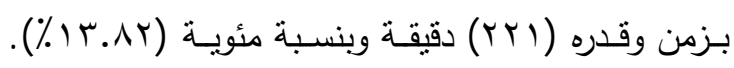

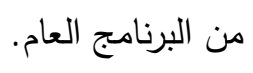

تخلـل البرنـامـج العوامـل المسـاعدة في بـرامج الإعداد

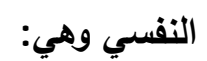

أ. التوجيه وقد استمر (r) جلسات تدريبية بزمن

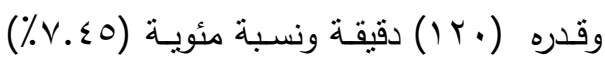

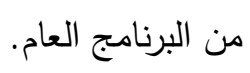

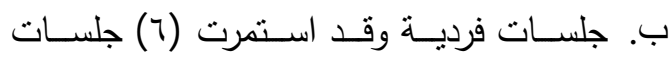

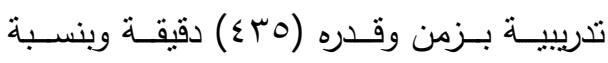

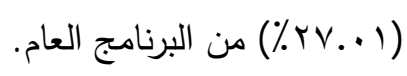

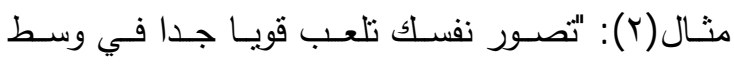

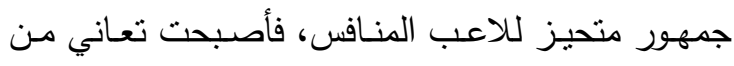

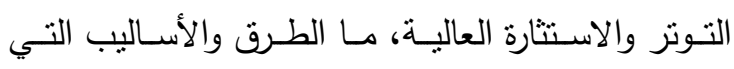
تستخدمها لتجاوز هذا الموقف بنجاح". • قبـل وبعد كل عمليـة تصـور عقلي يؤخذ الثـهيق والزفير العميقان. • قبل تتفيذ عملية تركيز الانتباه يؤخذ الثهيق العميق والزفير البطيء. واجبات منزلية. وقد استمر هذا البعد (اب) وحدة تدريبية، بزمن وقدره

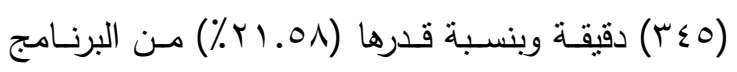

\section{Self-Talk البعد الثالث: الحديث مع الذات} يمثل هذا البعد جوهر برنامج الإعداد النفسي

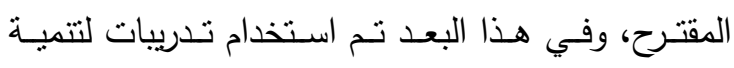
الحديث الذاتي الإيجابي بغرض التأثنر على المشـاعر

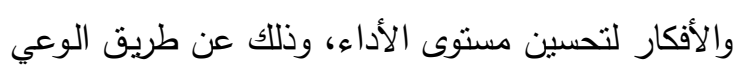

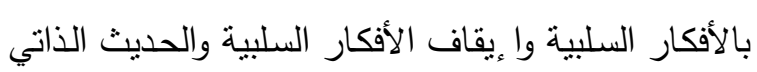

$$
\text { الإيجابي . - الإنار }
$$

الهدف:

تتمية مهارات الحديث الذاتي الإيجابي، لتحسين مستوى الأداء وتوجيه التوتز للمستوى الأمنت . لإنيك.

\section{خطوات التنفيذ:}

ا. . يوضـح المـدرب للاعب بعـد الحديث مــع الذات (أهميته، أنواعه، طريقة استخدامه) مع ذكر أمنلة

$$
\text { على لاعبين عالمين. }
$$

r. تعليم اللاعب كيفية الوعي بالأفكار السلبية.

مثال: (اختر ثلاثة أيام، ركز خلال تلك الأيام على

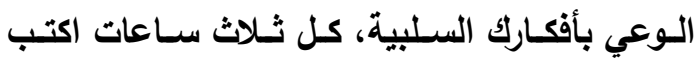
الأفكار السلبية التي استدعاها الموقف الذي حدثت لـاتهات 
خطوات إجراء الدراسة:

1 - تم إجراء (القياس القبلي) وفقا للخطوات التالية:

كون الباحثنان أعضـاء في مجلس

ادارة نـادي عمــان الرياضــي قــاموا

بتتظـيم بطولــة وديــة بنظـام خـروج

المغلوب من أول مرة، للفئة العمريـة

المستهدفة (لاعبي النخبة) في تاريخ

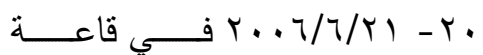

اليرموك بالمدينة الرياضية .

قـــام الباحثـــان بـإجراء الاختبـارات

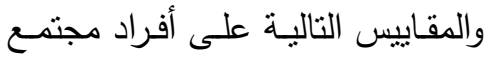

الدراسـة (حالـة قلق المنافسـة، تركيز

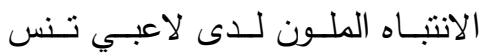

الطاولــة ، القــدرة على الاســترخاء)

وذلك قبل نصف سـاعة من مباراة

$$
\text { كل لاعب في قاعة اليرموك. }
$$

تم تصوير المباراة الأولى لكل لاعب بواقع شوطين من ثلاثة أشواط وذللك

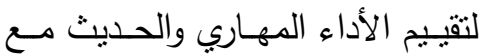

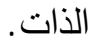

في اليوم التالي قام الباحثان بتوزيع استنبانه(التصـور العقلي في المجـال الرياضـي) وذلك بعـد الانتهاء مـن المباراة، حيث قام الباحثان بتوضيح

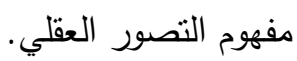
قيــام الحكــام (المســاعدين) بتقيــيم الحديث مـع الذات و الأداء المهاري

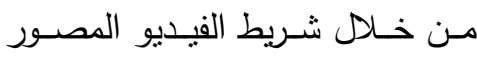
وتفريــغ البيانـات علـى الاسـتمارات

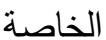

اختيـار عينـة الدراســة بنـاء علـى نتائجهم في اختبارات الدراسة.
تث. مناقتــة البرنـامج الروتيني قبـل المسـابقة وقـد

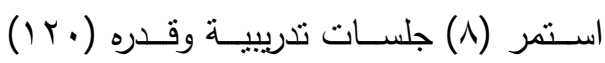

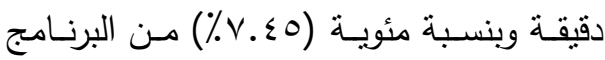

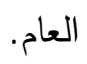

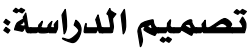

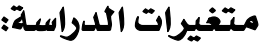

• المتغير المستقل:وهو البرنامج المقترح لبعض أساليب الإعداد النفسي، وتم اعتبار أساليب الإعداد النفسي وهي (الاسترخاء، التصور العقلي، الحديث مع الذات) متغيرات وسيطة (Entermediate) . • المتغيـرات التابعــة :هـــي المهـــارات النفســية (مواجهــة حالــة قلـق المنافسـة، تركيـز الاتنبــاه)

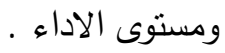

\section{الأدوات والأجهزة المستخدمة:}

1. لوح متحرك، أقلام White board ، ممحاة

r. شاشـة عرض، لاب توب/ Toshiba ، جهاز

داتا شو Data Show.

r. قاعة تتس طاولة ، كرات، طاولة تنس طاولة،

$$
\text { مضارب }
$$

ع. ملف خـاص بكل لاعب يحتوي على دفتر

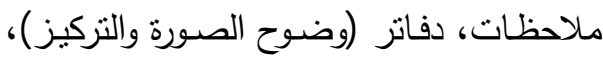
دفاتر (التركيز ، وللتحكم في الصـورة)، أقـلام

•.

$$
\text { صاخبة وهادئة) . }
$$

T. كاميرا فيديو Sony أثنرطة فيديو .

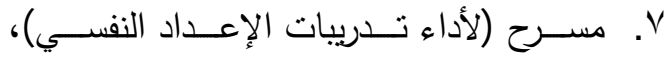
سماعات كراسي، مايك فرشات جمناستك

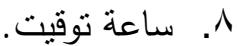




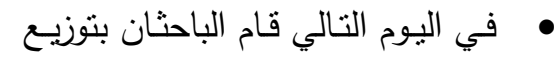

استبانه (التصسور العقلي في المجال

الرياضـي) وذلك بعد الانتهـاء مـن

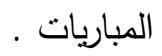

قيـام الحكـام (المســاعدين) بتقيـيم

الحديث مـع الذات و الأداء المهاري

مـن خـلال شـريط الفيـيو المصـور

وتفريــغ البيانـات علـى الاسـتمارات

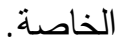

تطبيـق البرنـــامج المقتـرح لــبعض

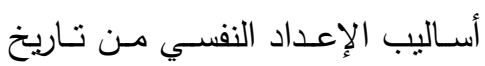

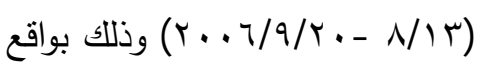

أربـع جلسـات تـدريب أسبـوعيا وفقـا

لخطة واء جراءات الدراسة.

r. تـم إجراء (القيـاس البعدي) وفقـا للخطوات

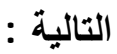

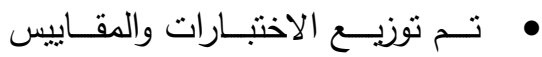

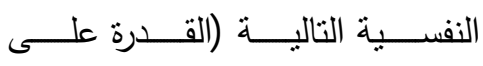

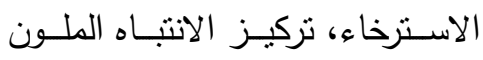

للدى لاعبي تنس الطاولة، حالة قلق القاه

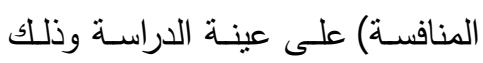

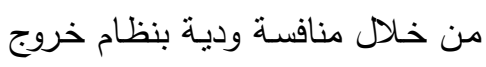
المغلـوب مـن أول مـرة والتي أقامها

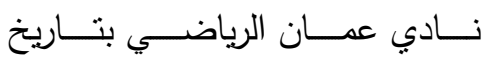

$$
. r \cdot T / 9 / r)
$$

نم تصوير المباراة الأولى لكل لاعب

بواقع شوطين من ثلاثة وذلك لتقيبم

الأداء المهاري والحديث مع الذات من بله ودين

فـي اليـوم التـالي قـام الباحثنـان بتوزيــع اسـنتبانه

(النصور العقلي في المجال الرياضي).
• قام الباحثان بتوجيه كتاب من عمادة

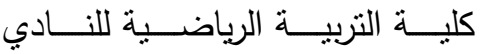

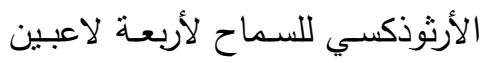

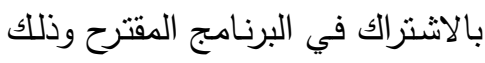

لتطبيق البرنامج المقترح عليهر.

بعد موافقة النادي الأرثوذكسي، قام

الباحثــان بإرســال كتــاب لأوليــاء

الأمور ، وذللك لموافقتهم على اشتراك

أبنــاءهم فــي البرنـــامج التــدريبي

$$
\text { المقترح. }
$$

• • بعد أن تم الموافقة من أولباء الأمور ،

قام الباحثنان بإجراء نطبيق البرنـامج

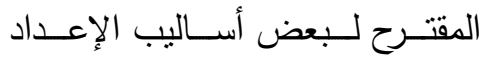

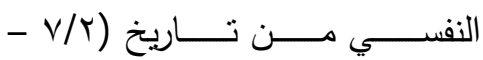

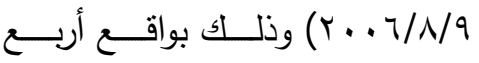

جلسات تدريب أسبوعيا ووفقا لخطة

$$
\text { واءجراءات الدراسة. }
$$

r. تـم إجراء (القياس التتبعي) وفقا للخطوات

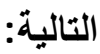

تــــــــــع الاختبــارات والمقـاييس

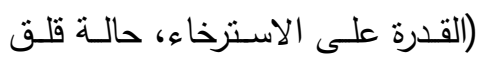

المنافسة، تركيز الانتباه الملون لدى الدى

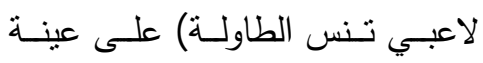

الدراسة وذلك من خلال منافسة ودية لاعية

بنظام خروج المغلوب من أول مرة و

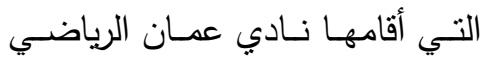

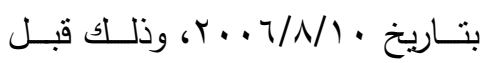

نصف ساعة من مباراة كل لاعب.

تم تصوير المباراة الأولى لكل لاعب

بواقع شوطين من ثلاثة وذللك لتقييم

الأداء المهاري و الحديث مع الذات. 
الاسترخاء للدى لاعبي تنس الطاولـة . فقد تم استخدام

اختبـار ويلكوكسـون وقيمـة الإحصـائي Z المحسـوبة لأسية

$$
\text { والجدول رقم (r) يوضح ذلك . }
$$

في ما يلي عرض لنتائج الدراسة تبعا لفروض الدراسة:

أولا: للتحقق من الفرض الأول : الذي يشير إلى وجود

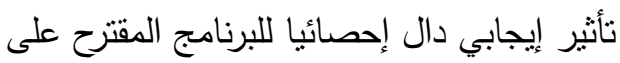

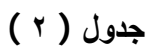

نتائج اختبار ويلكوكسون وقيمة الاحصائي Z المحسوبة لمقياس القدرة على

الاسترخاء بين القياسين القبلي والبعدي

\begin{tabular}{|c|c|c|c|c|}
\hline مستوى الدلالة & قيمة & متوسط الرتب & مجموع الرتب & اشارة فروق الرتب \\
\hline \multirow{2}{*}{$\ldots$. V } & \multirow{2}{*}{ T.rV } & . & . & سالبة \\
\hline & & $\varepsilon$ & rA & موجبة \\
\hline
\end{tabular}

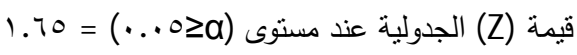

الاستجابة للضغط العصبي والمساعدة في الوصول إلى مسـتوى مـنخفض مـن التوتز , كمـا يتطلب الاسـترخاء المرتبط بموقع المنافسـة التدريب المتواصـل قبل وأثناء المنافسات وفي مواقف الحياة الضاغطة, ويشير كل من

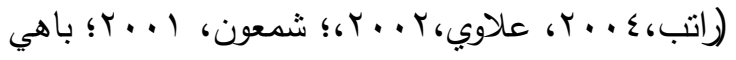

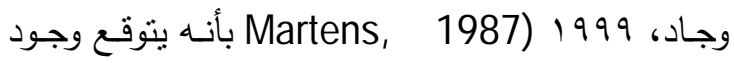
علاقة وثثقة بين تلك الأساليب والتي تلعب دورا أساسيا Hardy et al; (1996) في تحقيق التفوق، وما ذكره إلى أن الاسترخاء العضلي هو أكثر من مجرد أسلوب النوب

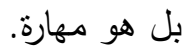

إن التحسـن في القدرة على الاسـترخاء جـاء نتيجـة

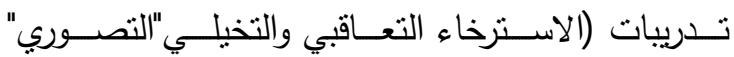
التصـور العقلي,الحديث مـع الذات ) متزايدة الصـوبة الصاءية وذلـك مسن خـلال وضــع اللاعـب فـي ظـروف غيـر ضـاغطة وضـاغطة ؛ فالاسـترخاء التخيلـي والتصــور العقلي جعل اللاعب يستحضر أو يتصور ، المكان الذي يثـعر بالراحـة فيـه مثير ، والتي من خلالها يستحضـر

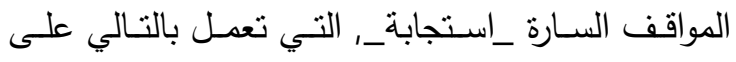

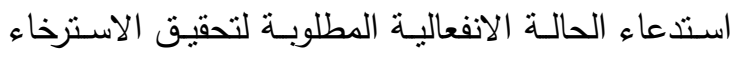

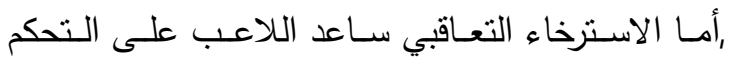
والسيطرة وخفض التوتز الذي انتابـه قبيل اشتراكه في المنافسـة وقبـل تطبيـق البرنـامج المقترح , وان اسـتخدام
يبـين الجـدول (r) نتـائج اختبـار ويلكوكسـون وقيهـة الإحصـائي Z المحسوبة لمقياس القدرة على الاستترخاء

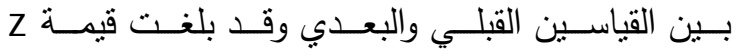
المحسوبة للاسترخاء القيمـة Y.TV وتعتبر هذه القيمـة دالة من الناحية الإحصائية حيث أنها كانت أعلى من هن

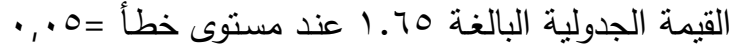
مما يعني إن الفروق في قيم متوسطات الرتب كانت جوهريـة بـين القياسـين القبلـي (قبـل تطبيـق البرنـامج) والقياس البعدي (بعد تطبيق البرنـامج) بحث أن الدلالـة كانت لصالح القياس البعدي.

أظهرت النتائج المتعلقة بـالفرض الأول، وجـود أتثر

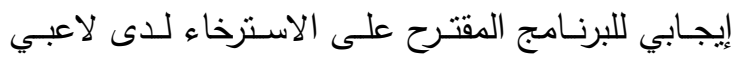
تنس الطاولة، وتعزى هذه النتائج إلى فاعليـة البرنامج

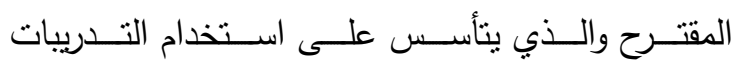

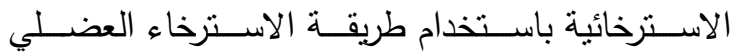

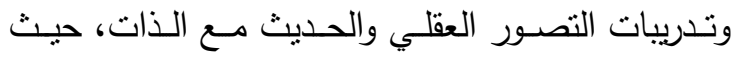
أنشار راتب (ع . . r) نقلا عن Edmund J acobson أنه عندما يتعلم الأفراد المقدرة على الاسترخاء فإن ردود الفعل تقل أو لا تحدث، وأن معرفة الفرد ومقدرته على التى لألى

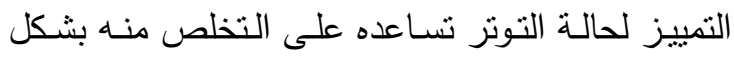

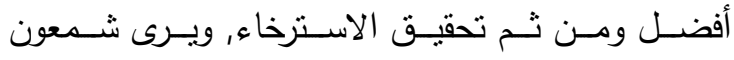

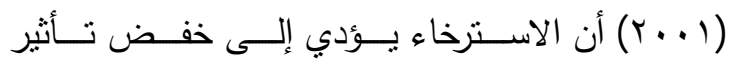




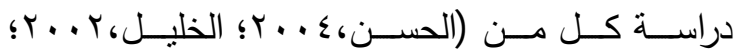
Rushall, 1996 الحديث مـع الذات في خفض التوتر وتحقيق الاسترخاء

\section{ويهذه النتيجة يتحقق الفرض الأول .}

ثانيا : للتحقق مسن الفـرض الثاني : الذي يشير إلى وجود تأثير إيجابي دال إحصائيا للبرنامج المقترح

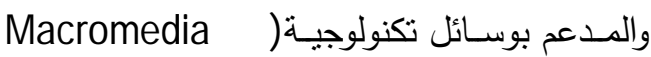
(Flash

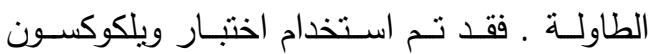
وقيمة الإحصائي Z المحسوبة والجدول رقم يوضح ذلك .
اللاعب كلمات" رموز" ايجابية أثناء تدريبات الاسترخاء

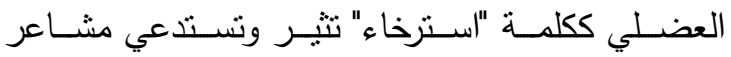

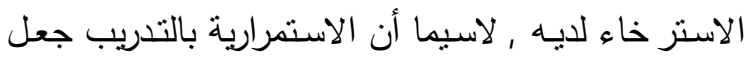

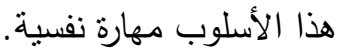

وتتفق هذه النتيجة مـع دراسـة كل من (السيد،

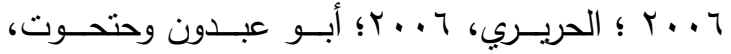

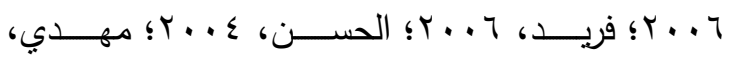

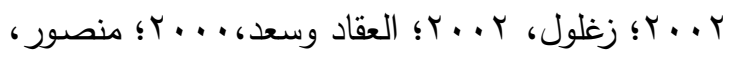

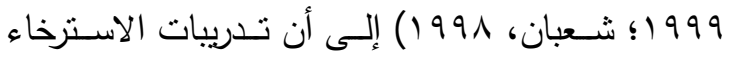
والتصـور العقلي تسـاعد اللاعبين على خفض التونز

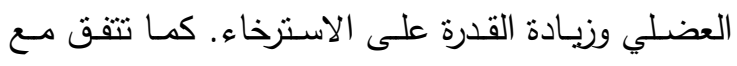

\section{جدول (r)}

نتائج اختبار ويلكوكسون وقيمة الاحصائي Z المحسوبة لمقياس التصور

العقلي بين القياسين القبلي والبعدي

\begin{tabular}{|c|c|c|c|c|c|}
\hline مستوى الدلالة & قيمة Z & متوسط الرتب & مجموع الرتب & الرثب & التصور العقلي \\
\hline \multirow{2}{*}{. $.1 \mathrm{~V}$} & \multirow{2}{*}{ T.rV } & . & . & سالبة & \multirow{2}{*}{ البصري } \\
\hline & & $\varepsilon$ & rA & موجبة & \\
\hline \multirow{2}{*}{. .17} & \multirow{2}{*}{ r.s. } & . & . & سالبة & \multirow{2}{*}{ السمعي } \\
\hline & & $\varepsilon$ & rᄉ & موجبة & \\
\hline \multirow{2}{*}{. .17} & \multirow{2}{*}{ T.\&. } & . & . & سالبة & \multirow{2}{*}{ الحس حركي } \\
\hline & & $\varepsilon$ & rA & موجبة & \\
\hline \multirow{2}{*}{$\ldots 1 \mathrm{~V}$} & \multirow{2}{*}{ T.rV } & . & . & سالبة & \multirow{2}{*}{ الانفعالي } \\
\hline & & $\varepsilon$ & rᄉ & موجبة & \\
\hline \multirow{2}{*}{..$+1 V$} & \multirow{2}{*}{ T.rV } & . & . & سالبة & \multirow{2}{*}{ التحكم } \\
\hline & & $\varepsilon$ & rᄉ & موجبة & \\
\hline \multirow[b]{2}{*}{$\ldots 1 \mathrm{~V}$} & \multirow[b]{2}{*}{ T.rv } & . & . & سالبة & \multirow[b]{2}{*}{ الكلي للتصور } \\
\hline & & $\varepsilon$ & rA & موجبة & \\
\hline
\end{tabular}

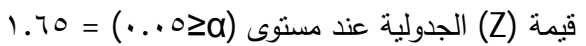

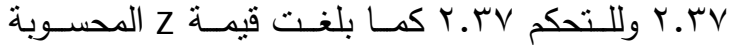
للتصور بشكل عام القيمة V.r. وتعتبر جميع هذه القيم

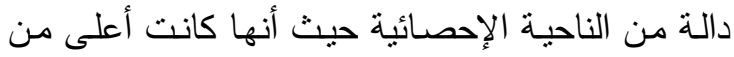

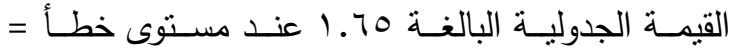
ه... مما يعني أن الفروق في قيم متوسطات الرتب كانت جوهرية بين القياسين القبلي (قبل تطبيق البرنامج)
يبيـن الجـدول (ب) نتـائج اختبـار ويلكوكسـون وقيمـة الإحصـائي Z المحسوبة لمقياس التصـور العقلي بين القباسـين القبلـي والبعدي وتـل قيمـة Z المحسـوبة

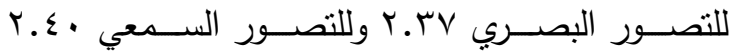
وللتصــور الحس حركي •ـ.ب وللتصــور الانفعـالي 
تـدريبات الوضـوح والتحكم بالصـورة هـي مراحل هامــة للقدرة على التصور العقلي التي يجب أن تحاكي الأداء

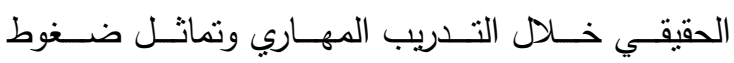

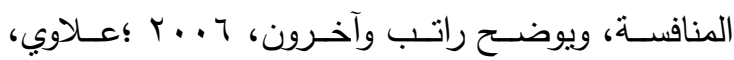

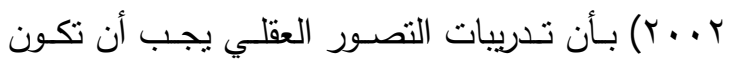
مصـدرا للاسـتمتاع وعـدم الثـعور بالملـل، ومــانـان ذكـره Hardy et al; (1996) أكثر من مجرد أسلوب بل هو مهارة نفسية.

كما إن التطور في التصور العقلي يرجع إلى التدريبات المختلفة التي تتاولت الأبعاد الحسيه التالية: (البصرية، السمعية، الحس حركية، الانفعالية) ومحاولة الارتقاء في هذه الأبعاد بطريقـة منكاملـة حتى يمكن

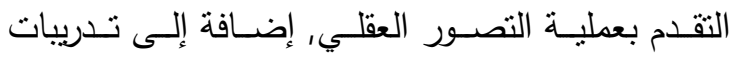

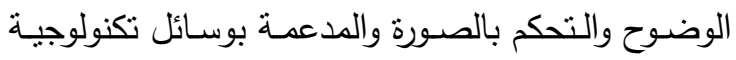
والتـي تحساكي الظـروف (Macromedia Flash) الحقيقية التي يواجهها اللاعب خلال المنافسة وذللك من

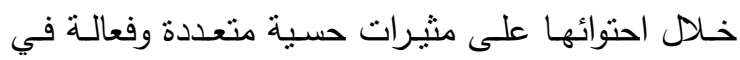

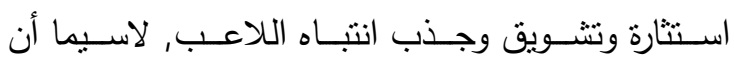
الاستمرارية في التدريب جعل هذا الأسلوب مهارة نفسية

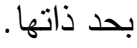

وتتفق هذه النتيجة مـع دراسـة كل من: السيد

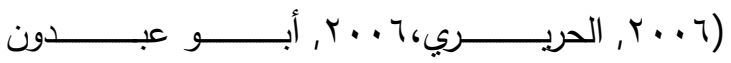

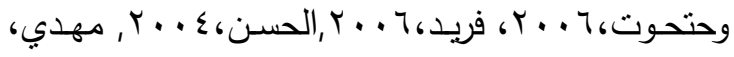

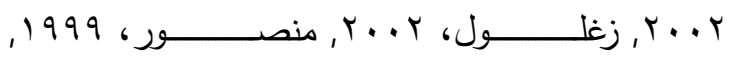

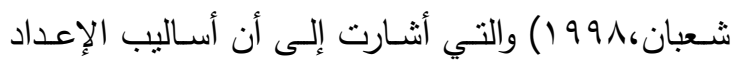
النفسي كالاسترخاء والتصور العقلي تعمل على تحسين

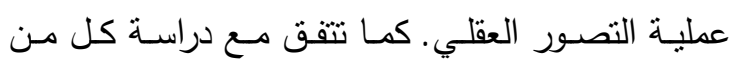

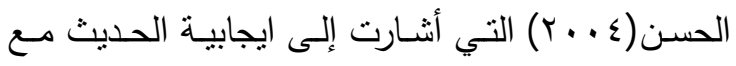
الذات في تطوير عملية التصور العقلي, كما اتفقت مـع العديد من الدراسـات على مختلف الأنشطة الرياضية،

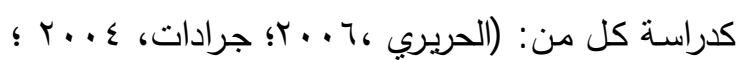

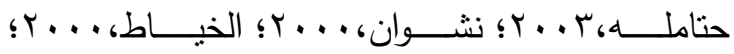
1998
والقياس البعدي (بعد تطبيق البرنـامج) وقد كانت هذه الدلالة لصالح القياس البعدي. وأظهرت النتائج المتعلقة بالفرض الثاني وجود أثر إيجابي للبرنـامج المقترح على التصـور العقلي للدى بلى

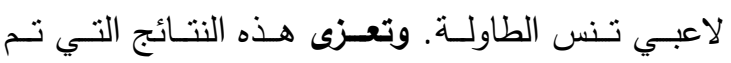

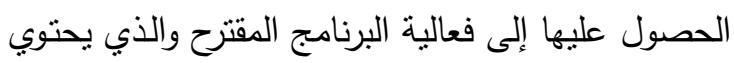

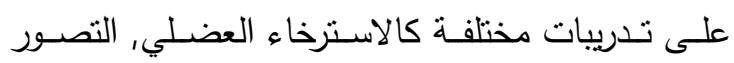

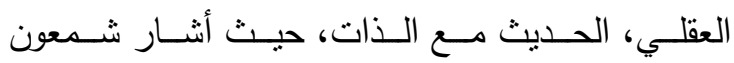

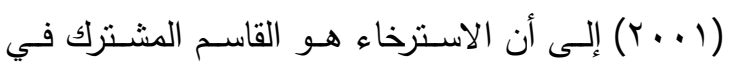

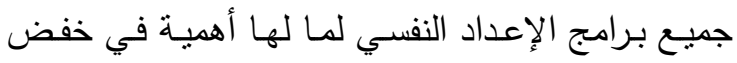
حدة التوتر والقلق وتهيئة المناخ النفسي والهدوء العصبي لتحقيق أفضل النتائج واتفق مـع كل من (راتب وآخرون،

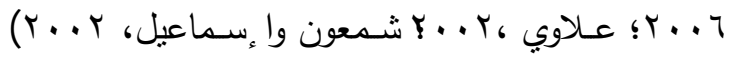

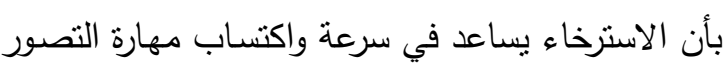
العقلي.

أن التحسـن في التصــور العقلـي يرجـع إلـى التى

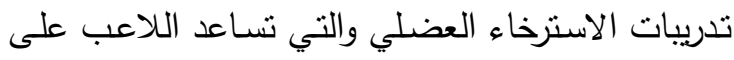

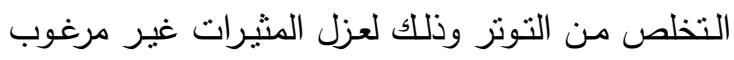
بها، حتى تمكن اللاعب من التصور العقلي بكفاءة، كما

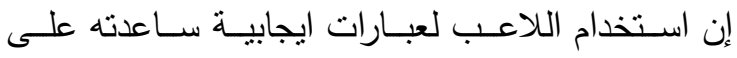

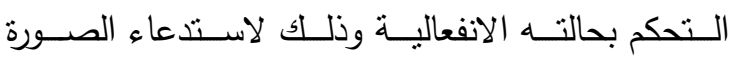

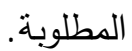

ويوضـح كـاظم وجـابر (919 () أن الخبـرات

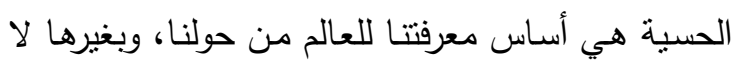
يمكن أن ندرك أو نعي أي شيء, وأن الوسائل التعليمية

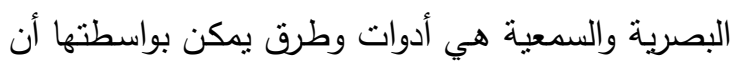

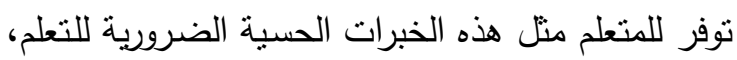

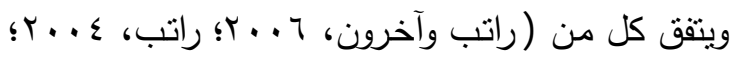

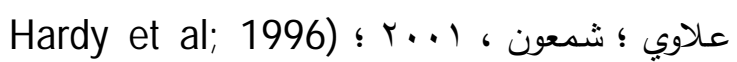
بأنه عند تطوير التصور العقلي يجب أن يكون اللاعب

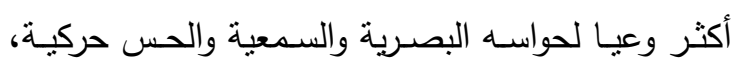

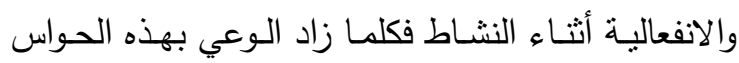
استطاع اللاعب خلق تصور واضح وحيوي للمهارة، وأن 
ثالثا : للتحقق من الفرض الثالث: الذي يشير الى وجود

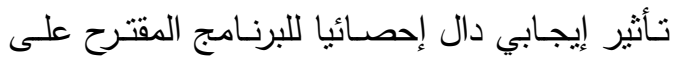
الحديث مـع الذات لدى لاعبي تنس الطاولة . فقد Z ت استخدام اختبار ويلكوكسون وقيمة الإحصائي المحسوبة والجدول رقم (ع ) يوضح ذلك . فernacchia \& cook,1993 التي أثنارت إلى فاعليـة برامج الإعداد النفسي باستخدام وسـائل تعليميـة

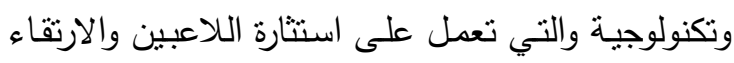

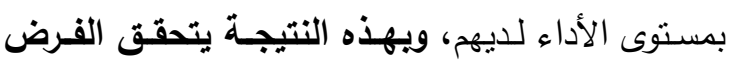

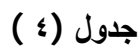

نتائج اختبار ويلكوكسون وقيمة الاحصائي Z المحسوبة الحديث مع الذات بين

\begin{tabular}{|c|c|c|c|c|c|}
\hline \multicolumn{6}{|c|}{ القياسين القبلي والبعدي } \\
\hline مستوى الدلالة & قيمة Z & متوسط الرتب & مجموع الرتب & إثشارة فرق الرتب & لحديث مع الذات \\
\hline \multirow{2}{*}{$\ldots 1 \mathrm{~V}$} & \multirow{2}{*}{ t.rV } & . & . & سالبة & \multirow{2}{*}{ الايجابي } \\
\hline & & $\varepsilon$ & rA & موجبة & \\
\hline \multirow{2}{*}{$\ldots .17$} & \multirow{2}{*}{ T.\&. } & $\varepsilon$ & rA & سالبة & \multirow{2}{*}{ السلبي } \\
\hline & & . & . & موجبة & \\
\hline
\end{tabular}

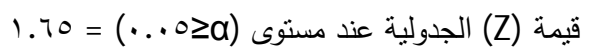

اللاعب على التحكم بالضغوط المعرفية وذلك لمساعدته على اكتشـاف طـرق لتغييـر تلـك الأفكـار واسـتبدالها بالحديث الإيجابي؛ وأنه من خلال عملية التصور العقلي

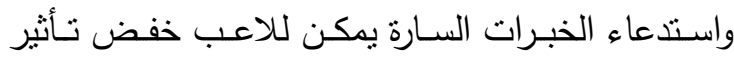
الاستجابة للضغط العصبي وخفض مستوى القلق العالي Hardy et al; (1996) وبناء الثقة بالنفس، وما ذكره إلى أن الحديث مـع الذات أكثر من مجرد أسلوب لأنـه

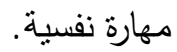

إن اللاعب من خـلد وعيه لتلك الأفكار السلبية التي تتنابه خلال مواقف متعددة يستطيع تحديد المواقف التي تستدعي تلك الأفكار ـ وباعتبار أن الاسترخاء العضلي لئي

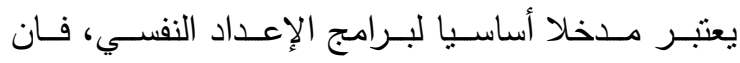

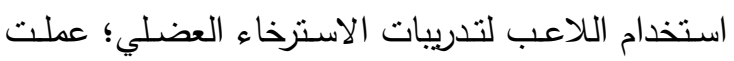
على خفض مسـتوى التـوتز لديـه والتي جعلتهـه بالتـالي يبتعـد عـن تفسـير الأعـراض الجسـمية بطريقـة سـلبية

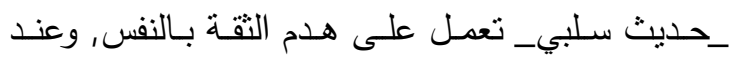

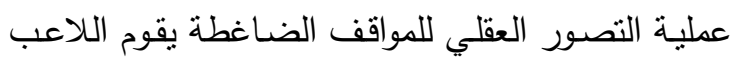

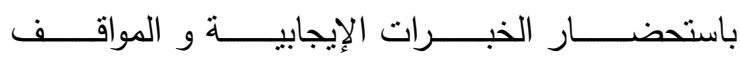
المتوقعة_مثثر _ التي قد يمر بها؛ والعمل على مواجنها

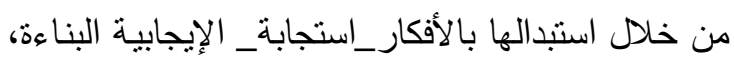

يبين الجدول (ع ) نتائج اختبار ويلكوكسون وقيمـة الإحصـائي Z المحسوبة لأداة الحديث مـع الذات

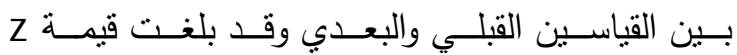
المحسـوبة للتحـدث الايجـابي V.r.r وللتحـدث السـلبي

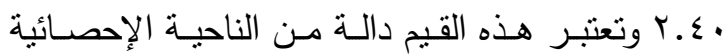
حيث أنها كانت أعلى من القيمة الجدولية البالغة 10.

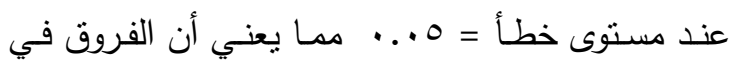
قيم منوسطات الرتب كانت جوهرية بين القياسين القبلي

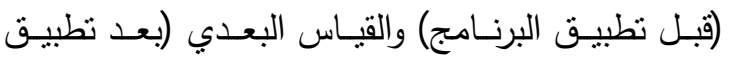
البرنامج) حيث ان الدلالة كانت لصالح القياس البعدي. أظهرت النتائج المتعلقة بالفرض الثالث وجود

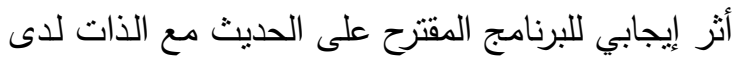

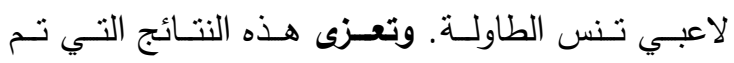
الحصول عليها إلى فعالية البرنامج المقترح ومـا يحتويـا لنديه

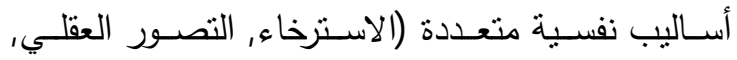

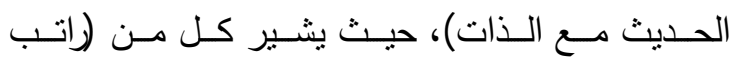

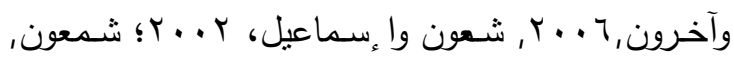
Bunker et al Hardy et al; 1996 r... 1993,، أ، (Weinberg,1988) أن الحديث مع الذات هي إحدى استراتيجيات الإعداد النفسي؛ التـي تسـاعد 
عبـارات التحـدث الايجـابي مـع الذات، ويهـذه النتيجـة

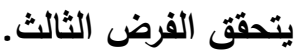

رابعا: للتحقق من الفرض الرابع: الذي يثير إلى وجود

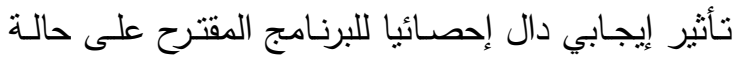
قلق المنافسة لاى لاعبي تتس الطاولة ـ فقد تم استخدام

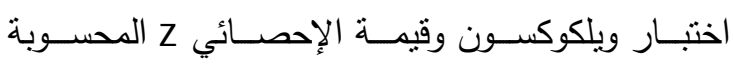
والجدول رقم ( 0 ) يوضح ذلك . .
حيث أن الاستمرارية في هذا السياق يجعل هذا الأسلوب

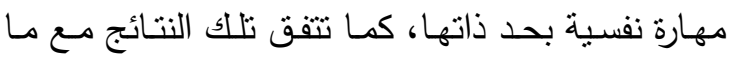

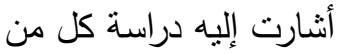

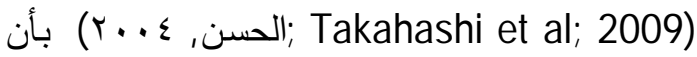

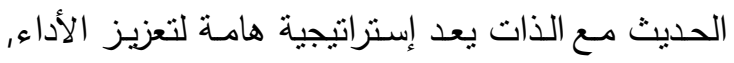
وأن برامج الإعداد النفسي تعمل على إكساب اللاعبين

\section{جدول (0)}

نتائج اختبار ويلكوكسون وقيمة الإحصائي Z المحسوبة لمقياس حالة فلق المنافسة

\begin{tabular}{|c|c|c|c|c|c|}
\hline \multicolumn{6}{|c|}{ بين القياسين القبلي والبعدي } \\
\hline مستوى الدلالة & قيمة & متوسط الرتب & مجموع الرتب & الثارة & أبعاد القلق \\
\hline \multirow{2}{*}{$\ldots, V$} & \multirow{2}{*}{ r.rv } & $\varepsilon$ & rA & سالبة & \multirow{2}{*}{ المعرفي } \\
\hline & & . & . & موجبة & \\
\hline \multirow{2}{*}{$\ldots+v$} & \multirow{2}{*}{ r.rv } & $\varepsilon$ & rA & سالبة & \multirow{2}{*}{ الجسمي } \\
\hline & & . & . & موجبة & \\
\hline \multirow{2}{*}{$\ldots, \mathrm{V}$} & \multirow{2}{*}{ T.rV } & . & . & سالبة & \multirow{2}{*}{ الثقة بالنفس } \\
\hline & & $\varepsilon$ & rג & موجبة & \\
\hline
\end{tabular}

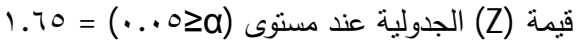

الذات) وأثزهـا على مواجهة حالـة قلق المنافسـة متعددة

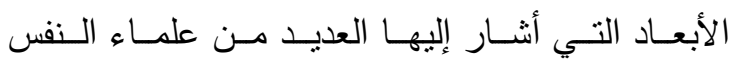

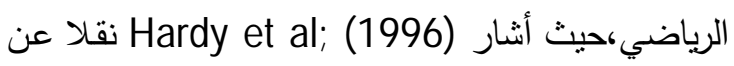
Davidson \& shwartz

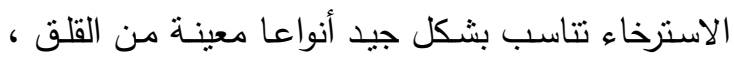

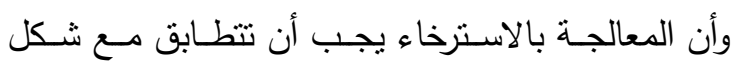
القلق الذي يمـر بــه اللاعب،ويوضـح شـمعون (999 (199 )

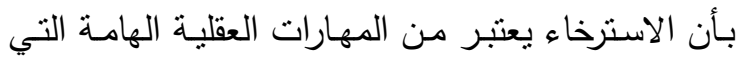
تسـاعد علـى الـتحكم فـي الضـــوط وتوجيــه الإثـارة

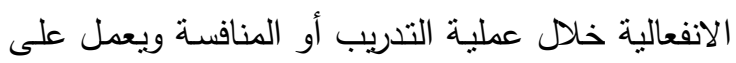

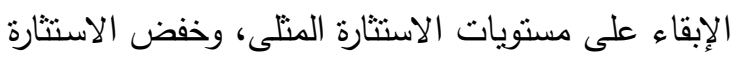

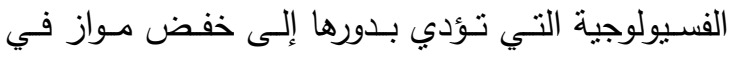

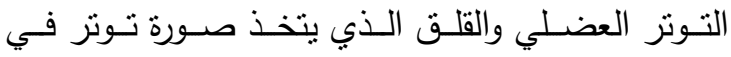
المجموعات العضلية الكبيرة. إن اسـتخدام تـدريبات الاسـترخاء العضـلي أدى إلىى

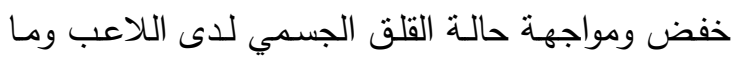

يبين الجـدول (0) نتائج اختبـار ويلكوكسـون وقيمــة الإحصــائي Z المحســوبة لمقيــاس حالــة قلـق المنافسة بين القياسين القبلي والبعدي وقد بلغت قيمة

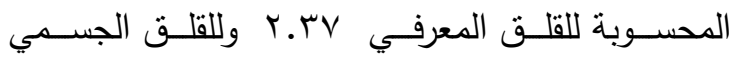

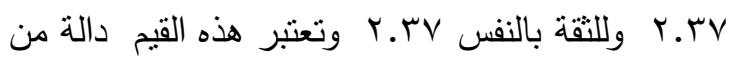

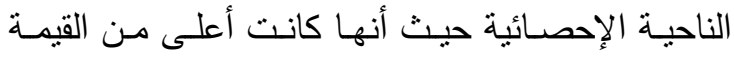

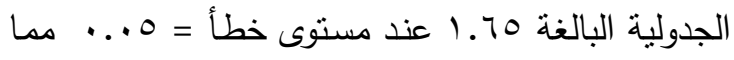
يعني أن الفروق في قيم منوسطات الرتب كانت جوهرية

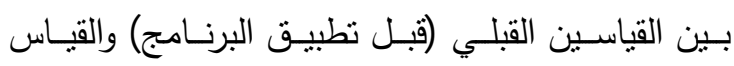

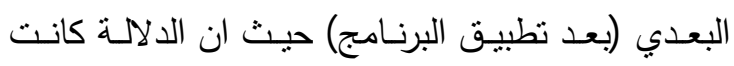
لصالح القياس البعدي. أظهرت النتائج المتعلقة بالفرض الرابع وجود

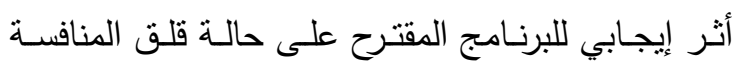
لاى لاعبي تتس الطاولة، وتعزى هذه النتائج إلى فعالية

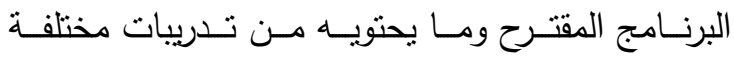

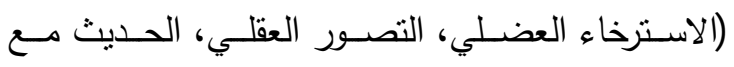


انخفـاض حالــة القلـق المعرفي لـدى اللاعـب خــلد

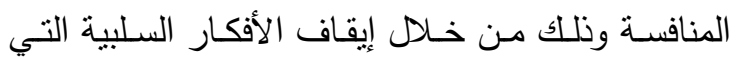

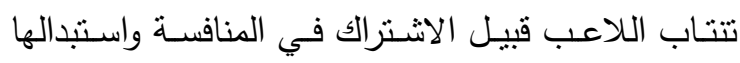

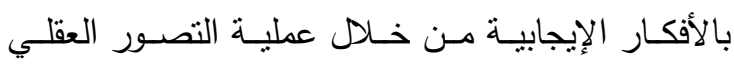
للموقف وذلك لإعادة وتكوين الأحداث التي ظهرت فيها لإنها

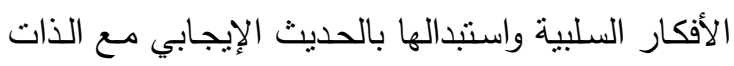
كالكلمـات (التشـجيعية والتقيميـة) التي تعمل على بلى بنـاء التقة بالنفس وخفض مسنوى القلق المعرفي - استجابة -

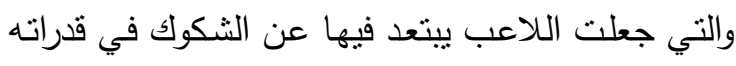
التي ظهرت عليـه قبل المنافسـة وقبل نطبيق البرنـامج المقترح، وتتفق هذه النتيجـة مـع نتائج دراسـة كل من :

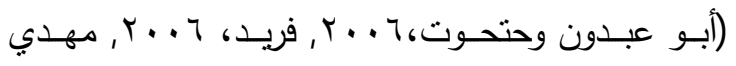

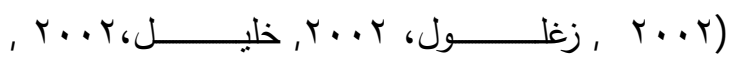

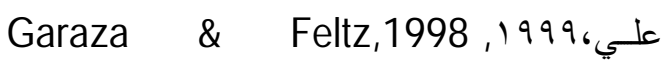
‘(Savoy,1993, Cox,1996 Rushall,1996, والتـي أثـارت إلى فاعليـة بـرامج الإعداد النفسي على

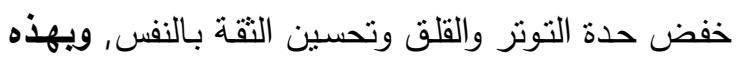

\section{النتيجة يتحقق الفرض الرابع.}

خامسا: للتحقق من الفرض الخامس : الذي يشير إلى

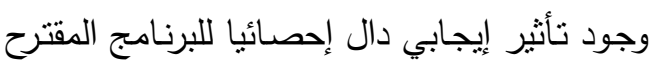

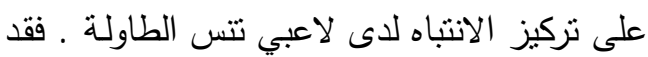
تم استخدام اختبار ويلكوكسون وقيمة الإحصـائي Z المحسوبة والجدول رقم (7) يوضح ذللك.
يـرتبط بتلك الحالــة مـن مظـاهر فسيولوجية (كالتعرق، ارتعاش الأطراف) التي تجعله بدورها يبتعد عن تفسير

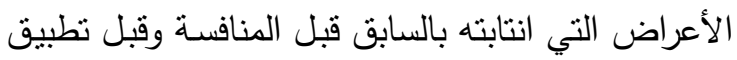

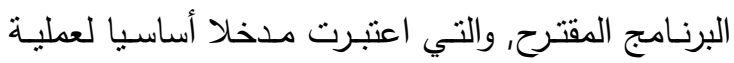
التصور العقلي والحديث مع الذات.

يؤكد راتب (ع . r) أن استخدام الفرد لحواسـ أنثاء عملية التصسور العقلي واستحضـار الصسورة الذهنية التي

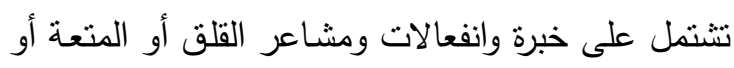

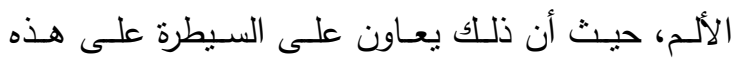

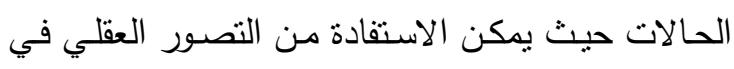
اكتساب القدرة على المواجهة والسبطرة على الانفعالات

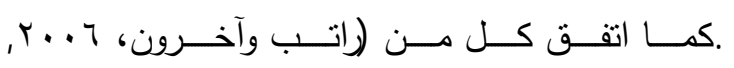

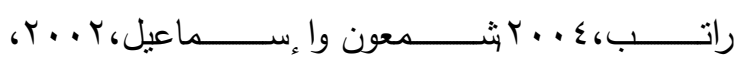

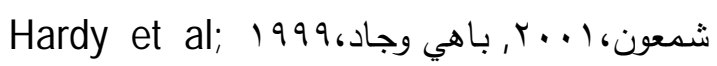
1996, Bunker et al; 1993 . إن أفضل طريقة

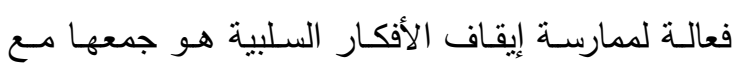
التصسور العقلي وذلك من خلال استحضسار فكرة سلبية أو نمط تفكيري معين يمر بـه اللاعب ويرغب بالتخلص منـه ,ومـن خـلال استخدامه للكلمـات الترميزيـة ككلمــا قف" ثم استبدال الأفكار السلبية بالأفكار الإيجابية والتي ومني تعمل على خفض مستوى القلق المعرفي والتوتز وبناء

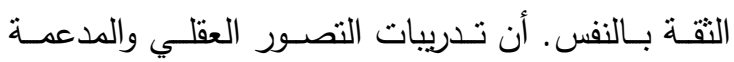

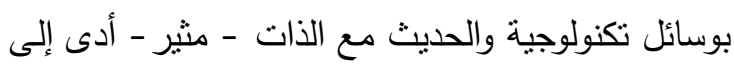
جدول (7) - ج (7)

نتائج اختبار ويلكوكسون وقيمة الاحصائي z المحسوبة لمقياس تركيز الانتباه الملون لاى لاعبي تنس الطاولة بين القياسين القبلي والبعدي

\begin{tabular}{|c|c|c|c|c|c|}
\hline مستوى الدلالة & قيمة & متوسط الرتب & مجموع الرتب & الثنارة & تركيز الانتباه \\
\hline \multirow{2}{*}{$\ldots 1 \mathrm{~V}$} & \multirow{2}{*}{ T.rV } & $\varepsilon$ & rA & سالبة & \multirow{2}{*}{ جموع نوعي الخطأ } \\
\hline & & . & . & موجبة & \\
\hline \multirow{2}{*}{$\ldots l v$} & \multirow{2}{*}{ r.rV } & . & . & سالبة & \multirow{2}{*}{ مجموع الأحرف } \\
\hline & & $\varepsilon$ & $r \wedge$ & موجبة & \\
\hline
\end{tabular}

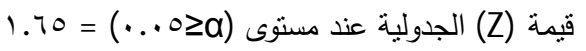

لاعبي تنس الطاولة بين القياسين القبلي والبعدي وقد يبـين الجـدول (7) نتـائج اختبـار ويلكوكسـون وقيمــة

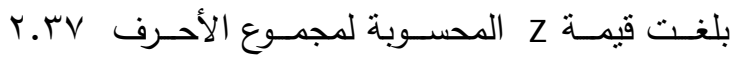
الإحصائي Z المحسوبة لمقياس التركيز الملون لدى لدئ 
البدنيـة والانفعاليـة والعقليـة على نحـو أفضـل وتجنـب الأفكار السلبية التي هي مصدر للقلق، ويضيف راتبه ولبد ( . . . ( ) أن تطوير مقدرة الرياضي على تركيز الانتباه

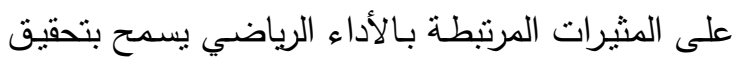

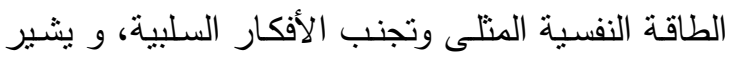

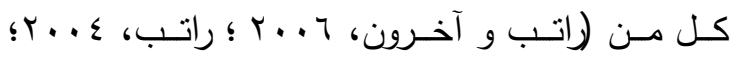

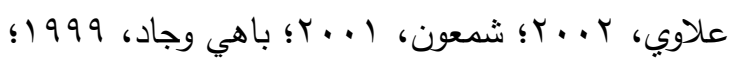

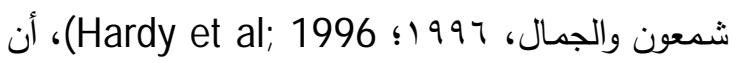
التصور العقلي يساعد على منع نتنتيت الأفكار وتركيز الانتباه خلال التصور العقلي للأشياء التي يريد أن يقوم

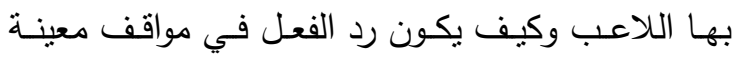
وايوضـ (1993) أن التحدث مواث.

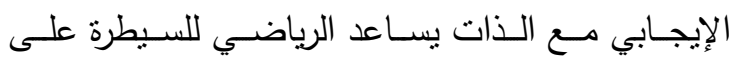

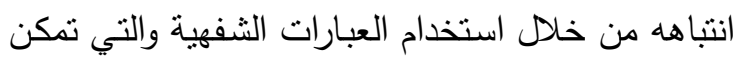
الرياضي من التركيز المناسب وعلى البقاء في الحاضر

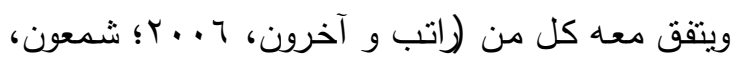

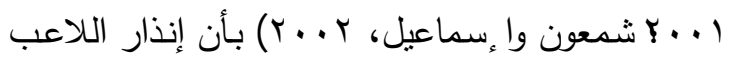
لنفسـه ككلمـة (قف) تعمل على نتـتيت تدفق الأفكار

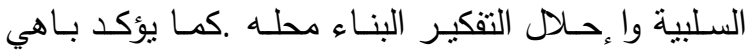

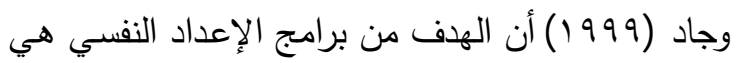

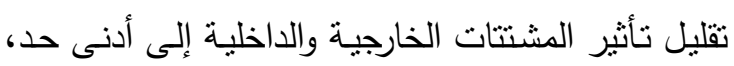
مع زيادة فرص التركيز الإرادي للرياضي إلى أقصى حد على المفاتيح اللازمة ذات الصلة.

إن تدريبات التصـور العقلي والمدعمـة بوسـائل

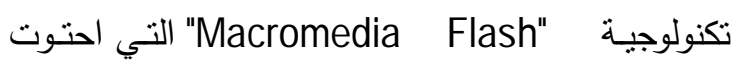

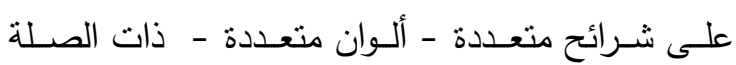
بالبيئة الرياضية والمصاحبة للأصوات الضوضائية التي لئي يتعرض لها اللاعبون خلال المنافسة والتي من خلالها يقوم اللاعب بالتركيز على استحضار الصورة المطلوبـة لهنية

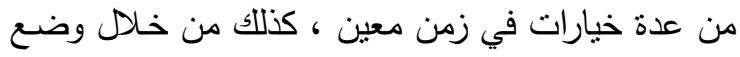
اللاعب في ظروف بيئية متعددة؛ فيبدأ بتركيز الانتباه

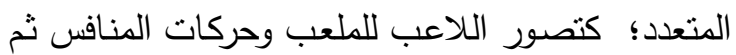
التفكير الايجـابي نحو تتفيذ الضـربات والتي يستدعون

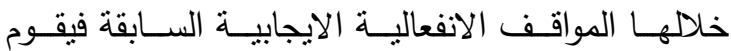

ولمجموع نوعي الخطأ Y.T. وتعتبر هذه القيم دالـة

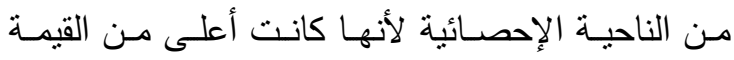

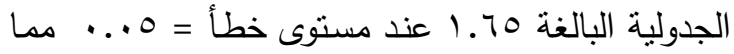
يعني أن الفروق في قيم منوسطات الرتب تعد جوهرية

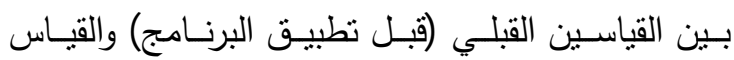

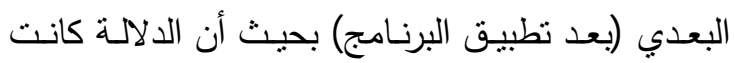

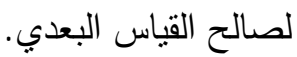
أظهرت النتائج المتعلقة بالفرض الخامس وجود

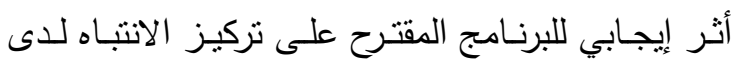
لاعبـي تنس الطاولـة، وتعـزى هـذه النتائج إلى فعاليـة

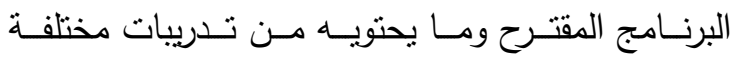

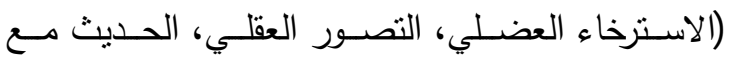

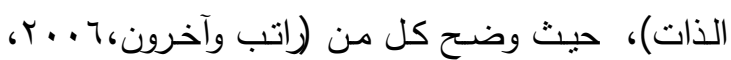

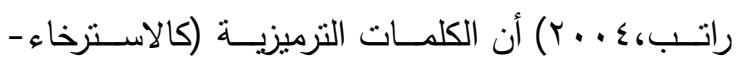

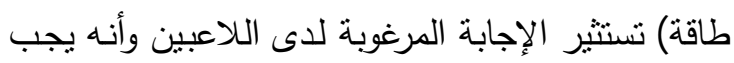
تـدريب اللاعبـين على تركيـز العـين على المثيـرات

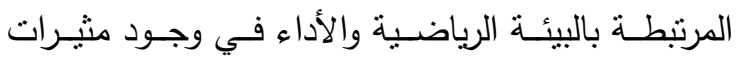

تشتت الانتباه والتي تكون مماثلة للظروف التتافسية.

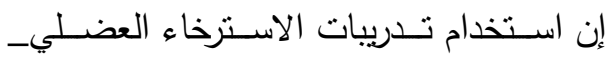

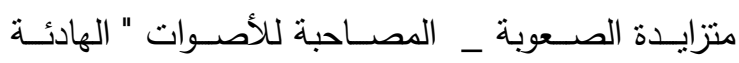
والصاخبة " تجعل اللاعب يركز على مشـاعر الاسترخاء

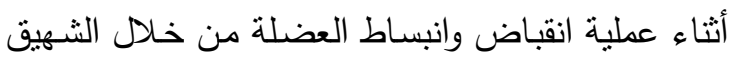

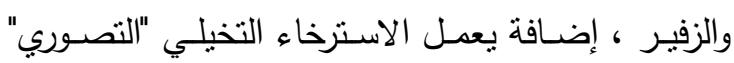

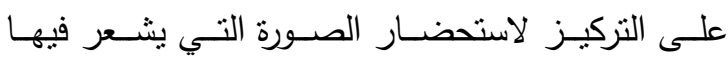

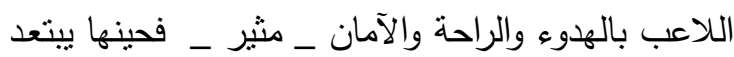
اللاعب عن تفسير الأعراض الجسمية غير المرتبطـة

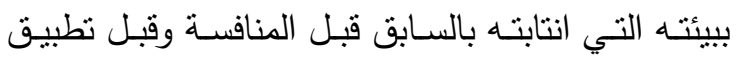

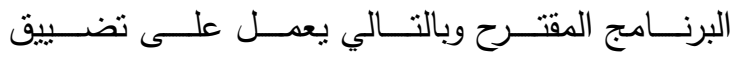

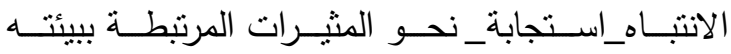
الرياضية الانية

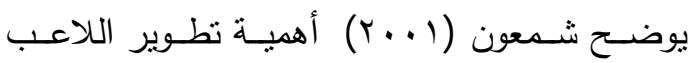

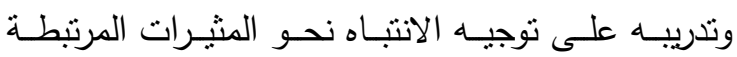
بالأداء، حيث أن ذلك يساعد اللاعب على تعبئة قواه 
Bakker \& زغلـول،r...r, منصـور، 1999، (Vernacchia \& Cook,1993 ، kayzer,1994

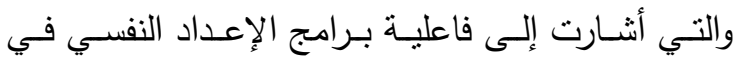

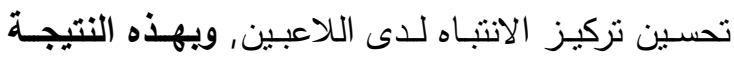
يتحقق الفرض الخامس. سادسا: للتحقق من الفرض السـادس: الذي

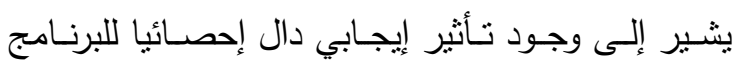

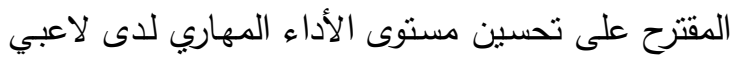
تتس الطاولة ـ فقد نم استخدام اختبار ويلكوكسون وقيمة الإحصائي Z المحسوبة والجدول رقم (V) يوضح ذللك.

اللاعب بـالتز كيز على مشـاعر الاسـترخاء و الحـديث الايجـابي مـع الــات مـن خــلال الكلمـات التشــيعية والتصحيحية - مثير - التي تعمل على إيقاف الأفكار السلبية والتي بدورها تؤدي إلى انخفاض ومواجهة حالة

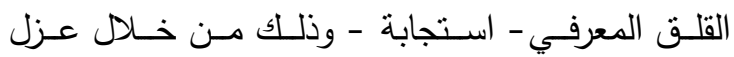

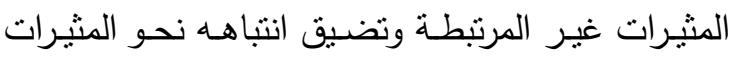

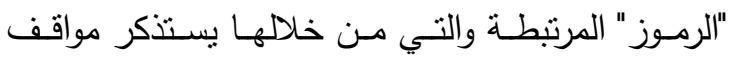
اللعب" كالضربة واتجاه الكره".

وقد اتفقت هذه النتيجة مـع دراسـة كل مـن:

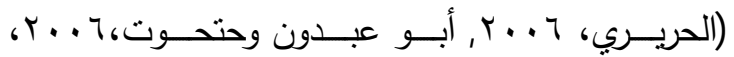

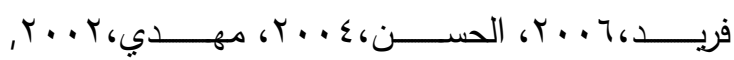

جدول (v)

نتائج اختبار ويلكوكسون وقيمة الاحصائي Z المحسوبة للأداء المهاري بين

\begin{tabular}{|c|c|c|c|c|}
\hline \multicolumn{5}{|c|}{ القياسين القبلي والبعدي } \\
\hline مستوى الدلالة & قيمة Z & متوسط الرتب & مجموع الرتب & اثنارة فرق الرتب \\
\hline \multirow{2}{*}{$\cdots+1 V$} & \multirow{2}{*}{ t.rV } & - & . & سالبة \\
\hline & & $\varepsilon$ & rı & موجبة \\
\hline
\end{tabular}

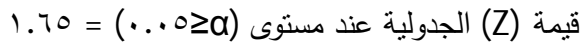

حتى يمكن التقدم بعملية التصور العقلي, لكل ما يختص

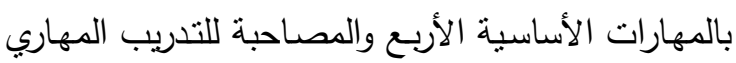
التقليدي, والتي أدت إلى الارتقاء بالمستوى المهاري لدى الدى

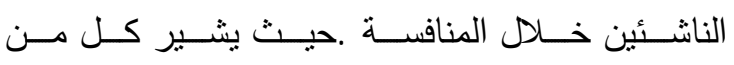

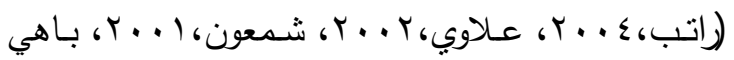

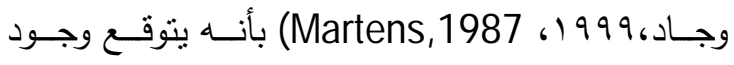
علاقة وثيقة بين تلك الأسـاليب والمهارات النفسية قيد

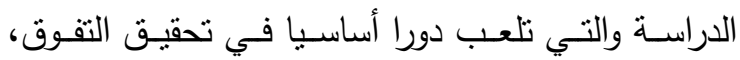
وأكدوا على أهمية برامج الإعداد النفسي المهاري، حيث ديث

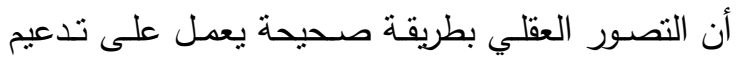

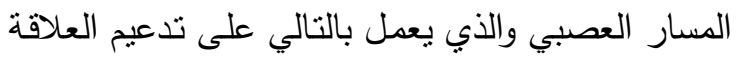
Hardy et al; بين المثير والاستجابة، ويوضح 1996

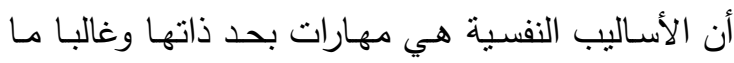
تستخدم كأساس للمهارات المتقدمة كالثقة بالنفس وخفض دهاب التهات القلق وتركيز الانتباه, وهي تساعد على تطوير مستوى

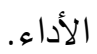

يبين الجـدول (V) نتائج اختبـار ويلكوكسـون وقيمـة الإحصــائي Z المحسـوبة لــأداء المهـاري بـين القياسين القبلي والبعدي وقد بلغت قيمـة Z المحسـوبة للاداء القيمة V.T.T وتعتبر هذه القيمة دالة من الناحية الإحصـئية حيث انها كانت اعلى من القيمـة الجدوليـة

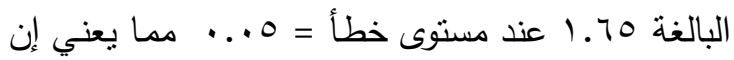

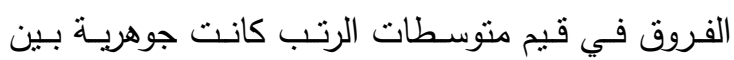
القياسين القبلي (قبل تطبيق البرنـامج) والقياس البعدي

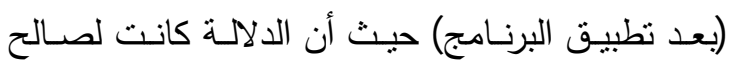

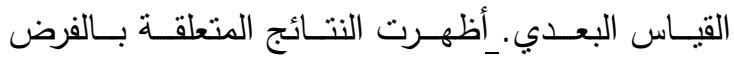
السادس بوجود أثز إيجابي للبرنامج المقترح على تحسين مستوى الأداء المهاري لاى لاعبي تتس الطاولة. وتعزى التى لئي

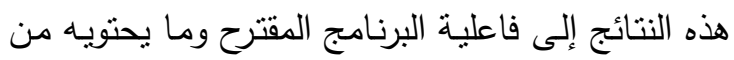
أسـاليب ومهارات نفسية (كالاسترخاء, التصـور العقلي لئي الحديث مـع الذات, مواجهة حالـة قلق المنافسـة, تركيز

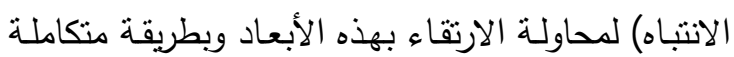


اللاعب أن يكـون في حالـة نفسـية" عقليـة " مسـتقرة ، والتي يمكنها أن تمنـع الأفكار السلبية ونتـتيت الانتبـاه

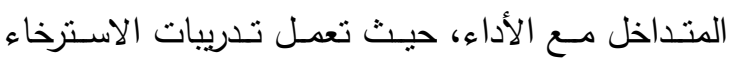

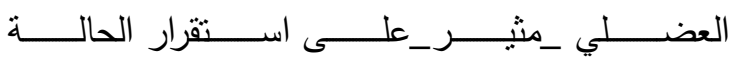
الانفعالية_استجابة_لـى لاعب تنس الطاولة، لاسيما

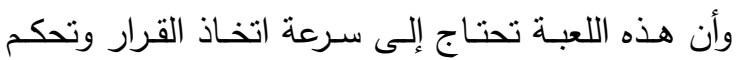

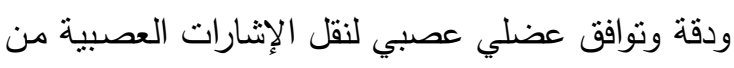
الهـخ إلى مختلف العضـلات المشتركة وانخفاض التوتر فيها، حيث أن تحقيق الاسترخاء فيها يؤدي إلى تتشيط وظائف التصور العقلي ذو الصلة بالأداء المهاري, وبما أن قانون لعبـة تنس الطاولـة يسمح للاعب بـذلك، فـإن اللاعب يتصور الأداء الصحيح تحت الضغوط المختلفة

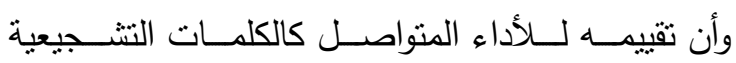
والتصـحيحية بعد كل نقطـة وخـلال فترة تبـادل الأمـاكن وتبادل الإرسال أدى إلى الارتقاء بمستوى أدائه المهاري، بُادي،

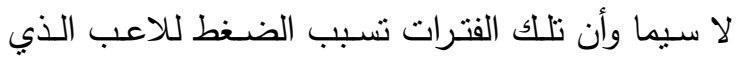

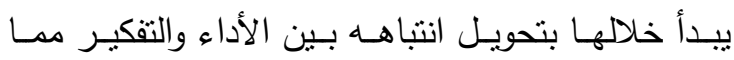
يؤدي إلى أخطاء عقلية تؤدي إلى أخطاء مهارية ناتجة عـن تشـنيت تركيـز الانتبـاه التـي تـؤثر على توقيـت إتى

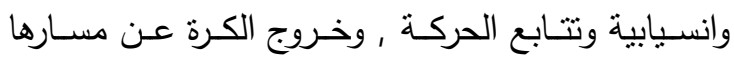

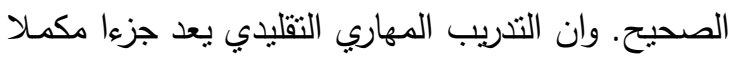
لبرامج الإعداد النفسي والتي لا يمكن فصلهما, حيث أن

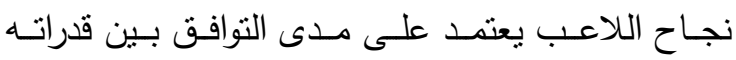
المهارية والعقلية .

وقد اتفقت هذه النتيجة مع دراسة كل من سالم

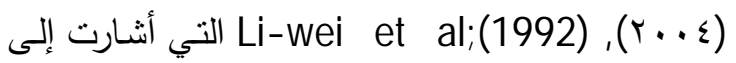

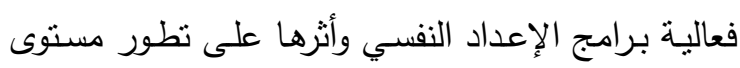
الأداء لاى لاعبي تتس الطاولة، وتتفق أيضـا مـع دراسة

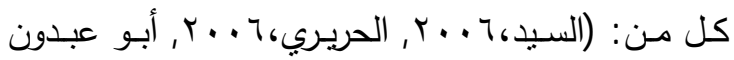

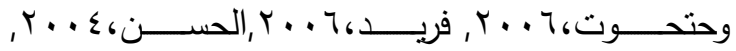

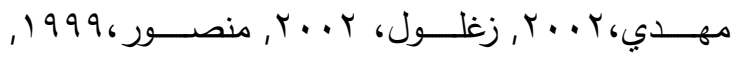

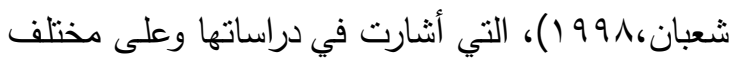

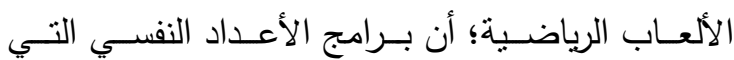

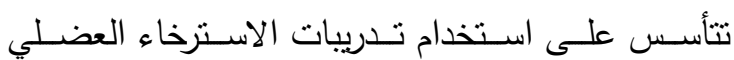

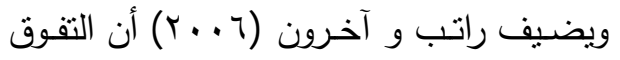

في الأداء يحدث عندما يكون اللاعب في منطقة الطاقة المتلى والتي هي من أهم خصائصها التحكم في تركيز

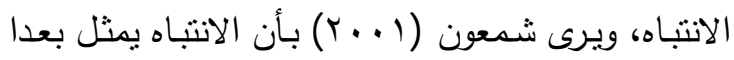

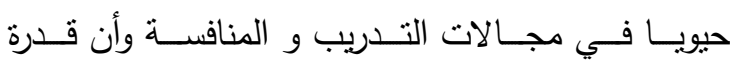
الرياضي على توظيفه؛ يعد من العوامل المؤثرة بصورة مباشـرة على أداء المهارات المختلفة وأنـه يجب التركيز على الأداء الصحيح فقط، حيث أن التصور العقلي غير

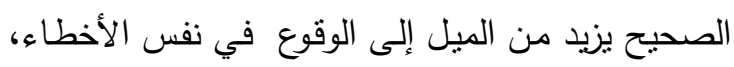

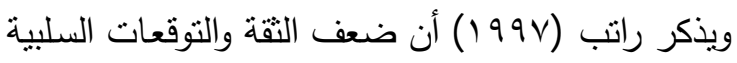
يضعف من كفاءة الأداء كما أنه يؤدي إلى حدوث القلق

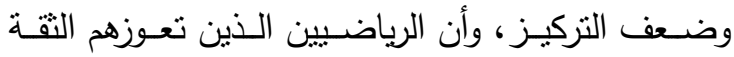

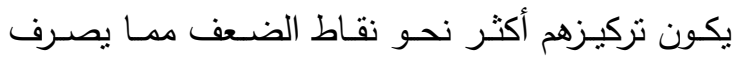

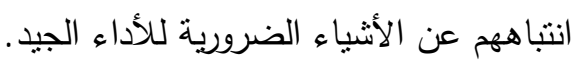

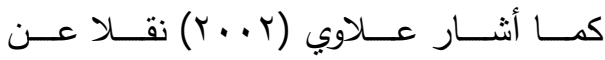

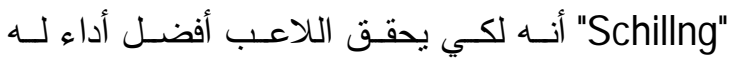
ينبغي أن يكون هناك تكامل وتوازن بين الوظائف البدنية

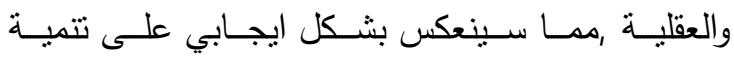
المهارات البدنيـة والحركية بشكل مسـاو لتتميـة القدرات العقلية, وعندئذ يستطيع اللاعب تحقيق الأداء الأفضل,

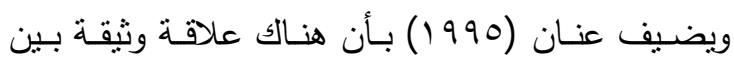
مستوى القدرات العقلية والتفوق الرياضي, مؤكدا على أن

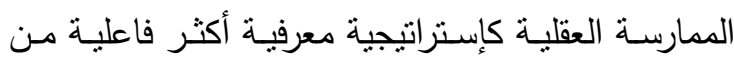

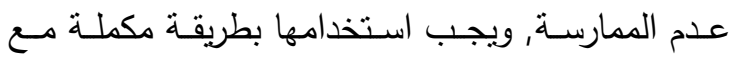

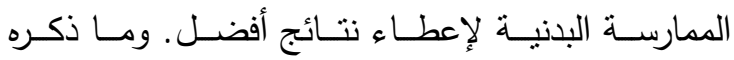

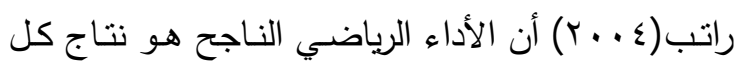

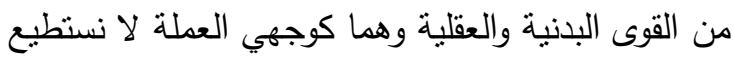

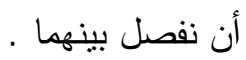

إن من خـلال توفير جو من التدريب الأمنتل يسـاعد اللاعبين على تتميـة المهارات الحركيـة بطريقة

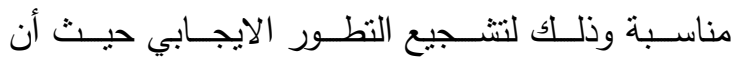
التـدريبات التي تتســ بالصـعوبة؛ تعدـل على الإمـداد

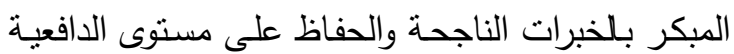

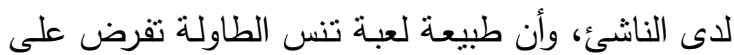


التدريب على بعض هذه الأساليب والمهارات

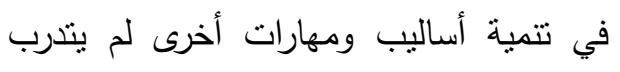

$$
\text { عليها . }
$$

التوهيات:

في ضـوء الاستنتاجـات التـي توصلت إليها الدراسـة،

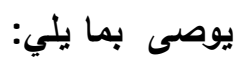

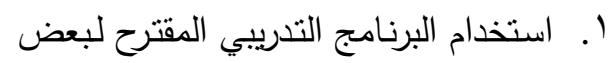

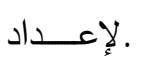

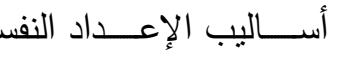

الممارس - ناشئ تتس الطاولة - نفسيا.

r

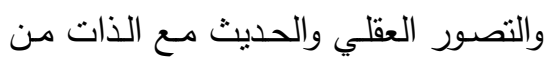

خلال برامج الإعداد النفسي التي تحاكي

ضغوط المنافسة.

r. تدعيم الأداء العملي - مهارات أساسـية

أربع - بالإعداد النفسي والمدعم بوسـائل

تكنولوجيـه لمـا في ذلك من أثر ايجابي

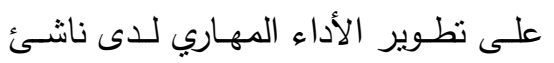
تنس الطاولة.

ع. الاهتمام ببرامج الإعداد النفسي المصاحبة

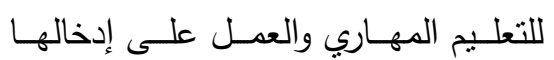

ضمن وحدات التدريب لما له من تأثثرات

واضــحة وا يُجابيـة فـي تطـوير المهـارات

الأساسية في تتس الطاولة.

0. التركيـز علـى تعلـيم اللاعبـين كيفيــة

الاسـتفادة مس اسـتخدام أسـاليب الإعـداد

النفسي في الفترة السـابقة للمنافسـة وفي الابـي

فترات الراحـة حتى يمكن تحقيق النتائج

$$
\text { سواء في التنريب أو المنافسة. }
$$

7. اســتخدام وســائل تعليميــة وتكنولوجيــهـ

متتوعة تعمل على استثاره وجذب وتشويق

اللاعبين .
والتصـور العقلي والمصـاحبة للتدريب المهاري لها أثر ايجابي على مستوى الأداء, وأكدت على أهمية الإعداد

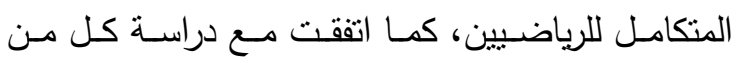

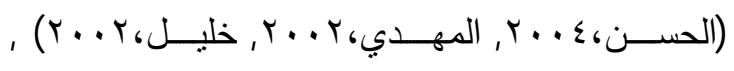
Van Raalte , schomer,1986, Rushall,1996 Rushall et ,Anderson,1993, et al.,1994 Meichenohoum \&Turk,1975 al;1988 أشنارت الى فاعلية الحديث مـع الذات وأثثره على تحسين

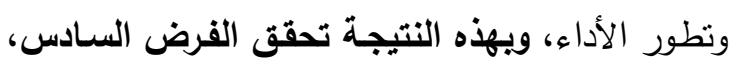
Scales فيما اختلفت هذه النتيجة مع دراسة (1998)

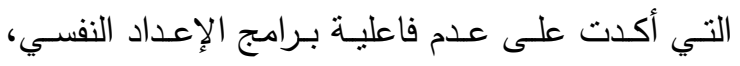

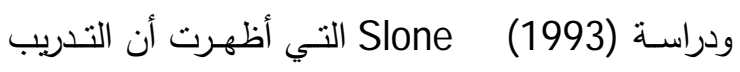
البدني أظهر تحسنا أفضل من التدريب البدني والنفسي.

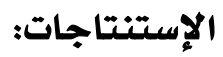

في ضوء أهداف وفرضيات الدراسـة وا جراءاتها يمكن

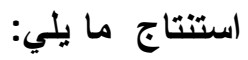

ا. البرنامج التدريبي المقترح لبعض أساليب

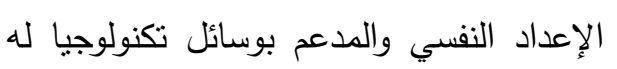
أثز إيجابي على تطوير الاسترخاء والتصور العقلي والحديث مع الذات .

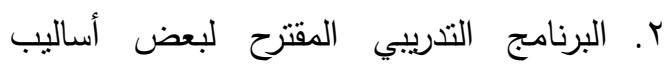

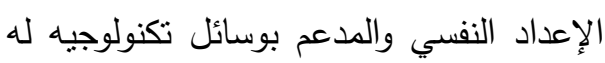
أثز ايجابي على تطوير بعض المهارات النفسية كمواجهة حالة قلق المنافسة وتركيز

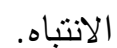
r. البرنامج التدريبي المقترح لبعض أساليب

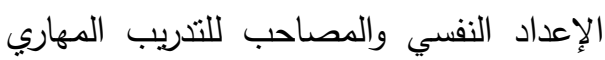
التقليدي له أثز ايجابي على تحسن مستوى ولاعي الأداء لاى لاعبي تنس الطاولة خلال المنافسة . ع. الأساليب والمهارات النفسية المختلفة تربطها العديد من العلاقات المتداخلة، حيث يسهر 
في تدريبات تتمية تركيز الانتباه لارتباطه

بمثيرات بيئية خاصة بلعبة تتس الطاولة .

^. أهميــة التـدريب النفسـي العقلـي المبكر

للاعبين حتى يمكن الاستفادة من البرامج

النفسية في الارتقاء لمستوى الأداء.
V . استخدام اختبـار تركيز الانتبـاه الملـون

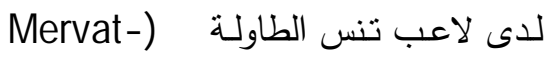

Colored Concentration Test for

: وذلك Table Tennis Players)

لتقدير مستوى تركيز اللاعبين واستخدامه 
تطوير بعض المهارات النفسية و تحسين الأداء الفني

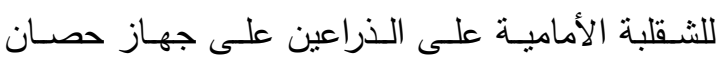

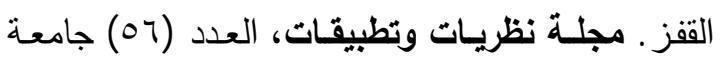
الإسكندر ية، مصر . حسن، وليد جبر (ع . . ب). فعالية الاسـتراتيجيات العقليـة على توجيه التوتر وتطوير مستوى أداء مهارات الهجوم

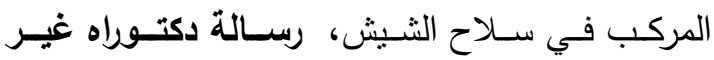
منشورة، جامعة حلوان، القاهرة مصر . خليفة، إبراهيم عبد ربـه ( ( . . r). التأهيل النفسي للاعب المصاب: المدخل النظري - أساليب النطبيق الإعداد النفسـي للبطـل الرياضــي (التوجهــات - النطبيقــات) الجمعية المصرية لعلم النفس الرياضي ، القاهرة . خليل، أحمد صلاح الدين (r . . r). النشاط الكهربائي للمـخ

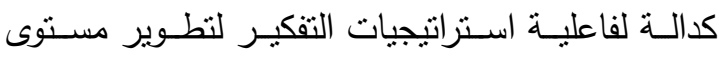

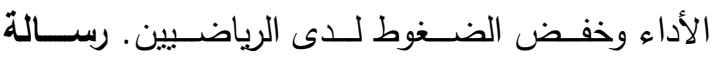
دكتوراه غير منشورة، جامعة حلوان، القاهرة، مصر .

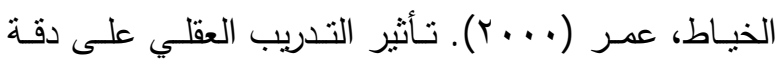

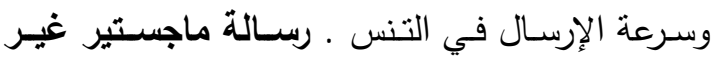
منشورة، الجامعة الأردنية، الأردن .

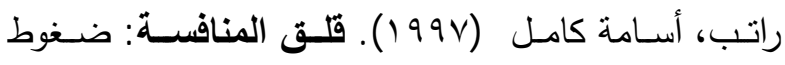

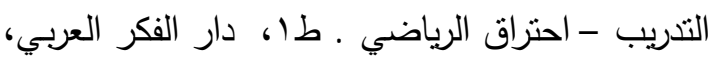
القاهرة. راتب، أسامة كامل (ع . . r). النشاط البدني والاسترخاء:

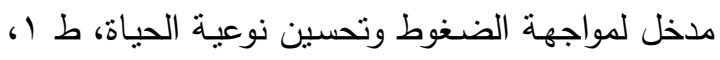

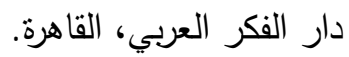

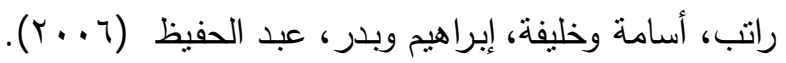
الإعداد النفسي للبطل الرياضسي ـ ط ال، دار الفكر

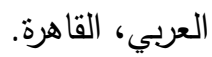

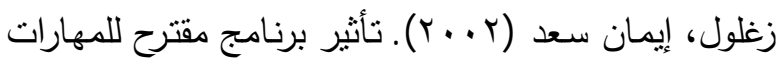
النفسية على تطوير الإيقاع الحركي ومسـتوى الأداء

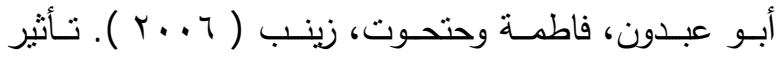

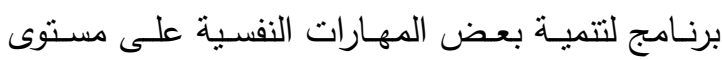

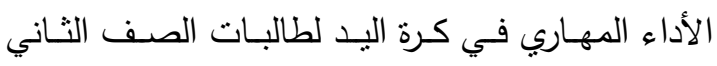

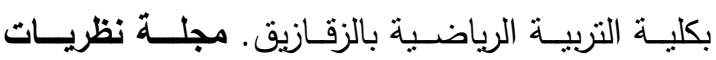

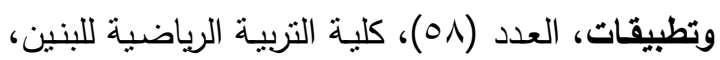
الإسكندرية. باهي، مصطفى وجاد، سمير (999 199 ). سيكولوجية التفوق

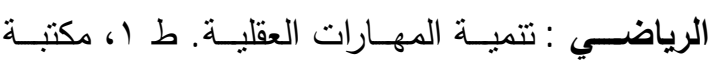
النهضة، القاهرة. البشيهي، محمد حسني (ع . ب ). تركيز الانتبـاه والتوجـه

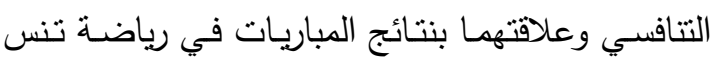
الطاولة. رسـالة ماجستير غير منشـورة، كلية التربيـة جامعة حلوان، القاهره. بدوي، عصام و راتب، أسامة، (ץ. . ب). التدريب الرياضي علم وفن . في لوري ودمان, دار الفكر العربي، القاهرة ،

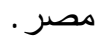

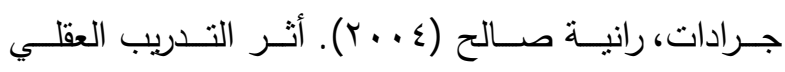
المصـاحب للتعليم المهاري في تعلم بعض المهارات الأساسية بكرة الطائرة. رسالة ماجستير غير منشورة، جامعة اليرموك، إربد، الأردن. الجمـل، جمـال (1990) ). دراسـة اسـتخدام بعض أسـاليب

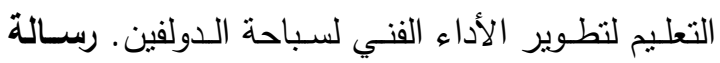
دكتوراه غير منشورة، جامعة طنطا، مصر . الحتاملة، مازن ( r . . ) ) تأثير استخدام برنامج التدريب

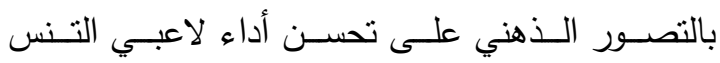

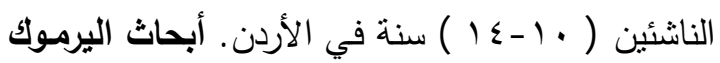

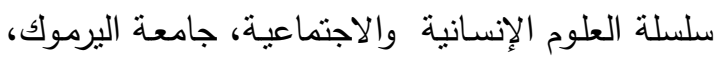

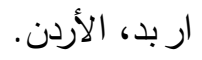

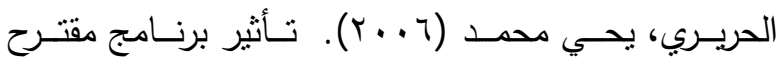

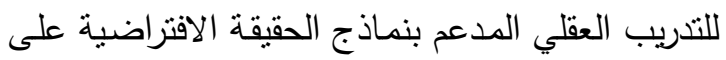




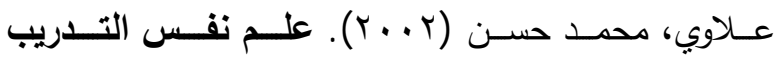
والمنافـــة الرياضــية. دار الفكـر العربــي، (ط ) ، القاهرة، مصر . علـي، رشـا إبـراهيم (999 ) ). تـأثنير برنـامج الاسـترخاء

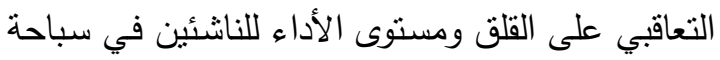
الزحف على البطن . رسـالة ماجستير غير منشورة، كلية التربية الرياضية، جامعة حلوان، القاهرة. عنـان، محمـود عبد الفتاح (1990) ). سـيكولوجية التربيـة

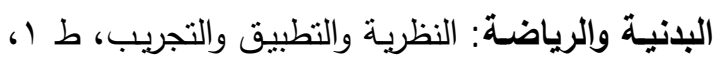

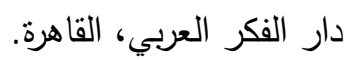

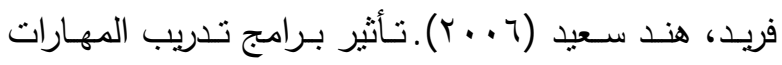

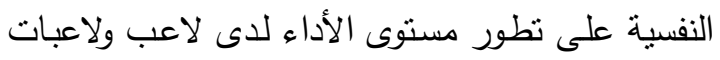
الخماسي الحديث. رسـالة دكتوراه غير منشورة، كلية التربية الرياضية، جامعة المنوفية، مصر . كاظم، أحمد خيري وجابر ، عبد الحميد (919 19) . الوسـائل التعليمية والمنهج، دار النهضة العربية, القاهرة.

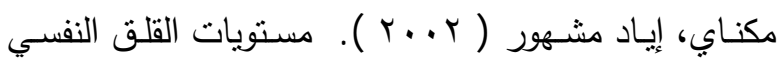

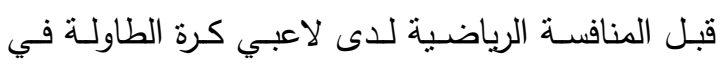
الأردن و علاقتهما بالانجاز الرياضي، رسالة ماجستير لاعي لكني غير منشورةه الجامعة الأردنية، عمان، الأردن . منصـور ، ســية محمـــ (1999) ). تـأثثر برنـامج مقتـرح

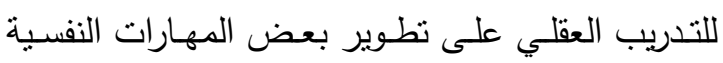
والمستوى المهاري والرقمي لمسابقة رمي الرمح لطالبات لئل الكلية. المؤتمر العلمي الحادي عشر التربية البلنية

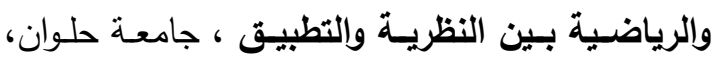
القاهرة. مهدي، نجلاء فتحي (r . . r). فعالية استخدام إستراتيجيات

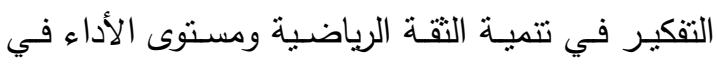

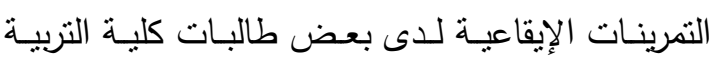
الرياضية في جامعـة المنوفيـة ، رسـالة دكتـوراه غيـر منشورة، جامعة حلوان،القاهرة.
لـ . عم/ حواجز . مجلـة الرياضــة علـوم وفنـ، (V)،

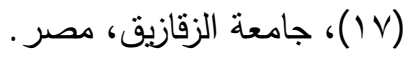

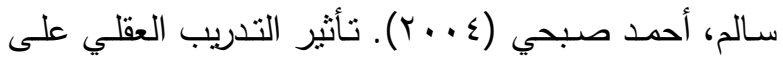
تطوير بعض المهارات الحركيـة لنانشئ تنس الطاولـة.

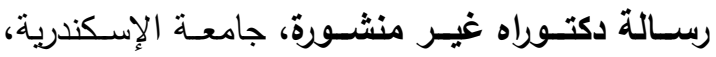
مصر .

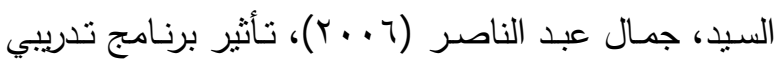
للمهارات النفسية على فاعلية الأداء لناشئ كرة القدم. رسالة دكتوراه غير منشورة، جامعة حلوان، القاهرة. شعبان، أسامة أحمد (991 (191) . تأثنير برنامج للتدريب العقلي على مستوى أداء بعض المهارات الحركية في رياضـة

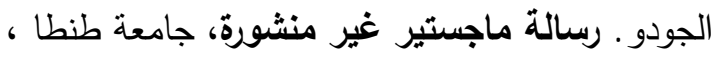

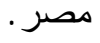

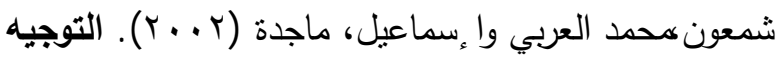

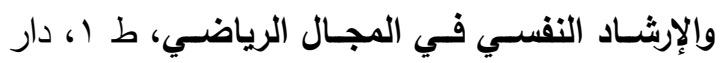

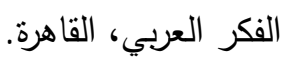

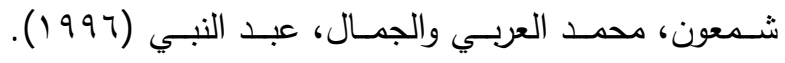
التدريب العقلي في التنس، ط ا، دار الفكر العربي، القاهرة.

شـمعون، محمد العربي (999 (1) ) علـم الـنفس الرياضسي والقياس النفسي، ط ا، مركز الكتاب للنشر، القاهرة.

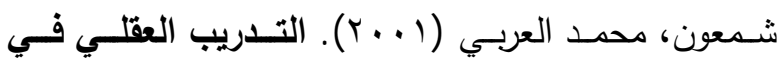
المجال الرياضي، ط ه دار الفكر العربي، القاهرة. العقاد، أحمد وسعد ممدوح ( ( . . . . ت تأثثر برنامج للتدريب

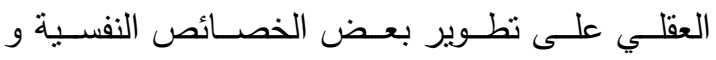

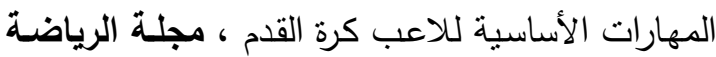

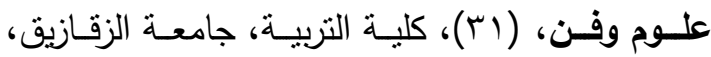
عـلاوي، محمـــ حسـن (1991) ). موســوعة الاختبــارات

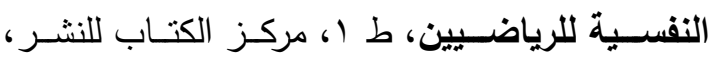
القاهرة. 


$$
\text { ماجستير غير منشورة، بغداد، العراق. }
$$

\section{المراجع الأجنبية:}

Anderson, A. T. (1993). The effect of an instructional self-talk program on learning a motor skill: The overhand throw. Dissertation Abstracts International, 54(1), 82.

Atienza, F. L., Balaguer, I., \& Garcia-Merita M. L. (1998). Video modeling and imaging training on performance of Tennis Service of 9 to 12-year-old children. Perceptual and M otor Skills, 87, 519-529.

Bakker, F. G., \& Kayser, C. S. (1994). Effect of a self-help mental training programe International Journal of Sport Psychology , $25,158-175$.

Bunker, L., \& Williams, J.M. (1993). Cognitive techniques for improving performance and building confidence. In J.M. Williams (Ed.), A pplied Sport Psychology: Personal growth to. peak performance (pp. 235-255). Palo Alto: Mayfield

Corbin, C. B., 1972. Mental Practice. In W.P. Morgan (Ed), Ergogenic aids and muscular performance (94-118).New York; NY: A cademic Press.

Cox, K. A. (1996). Effect of a psychological skills training program on competition anxiety and performance of selected National Youth Sports Program campers. Microform Publications, Int'I Institute for Sport \& Human Performance, University of Oregon.

Garza, D. L., \& Feltz, D. L. (1998). Effects of selected mental practice on performance, self-efficacy, and competition confidence of figure skaters: The Sport Psychologist, 12(1), 1-15.

Hardy, L., Jones, J. G. \& Gould, D. (1996). Understanding psychological preparation for sport: Theory and practice of elite performers. Chichester, England UK, John Wiley and Sons, Inc. (p.p11-41).

Li-Wei, Z., Qi-Wei, M., Orlick, T., \& Zitzelsberger, L. (1992). The effect of mental imagery training on performance

$$
\begin{aligned}
& \text { نشوان، عبد اله ( (. . ب). تأثثر التدريب الذهني في تعلم } \\
& \text { بعـض المهـارات الأساسـية فـي الملاكمــة، رســالة }
\end{aligned}
$$

enhancement with 7-10 year old children. The Sport P sychologist, 6, 230-241.

Martens, R. (1987). Coaches guide to sport psychology. Champaign, IL: Human Kinetics Publishers Inc.

Meicheuboum, D. ; Turk, D. (1975). The cognitive behavioral management of anxiety, anger and Pain , In P. Davidson (Ed),The behavioral man agree-ment of anxiety, depression and pain. New York; NY: Bruner Mazel

Nideffer, R. M. (1992) . Psyched to win. New York; NY: Macmillan.542-556.

Rushall , B.S. ; Hall , M .; Roux ,L.; Sasseville, J; \& Rush all , A . C.(1998). Effects of three types of thought content instructions on skiing performance. The Sport P sychologist, 2, 283-297.

Rushall, B. (1996). Some determinants in human performance: A psychological perspective, an invited keynote address presented at the Korean Society of Sport psychology summer seminar at Seoul Olympic Park, June 22. Retrieved from http://coachsci.sdsu.edu/csa/vol35/rushall1.ht $\underline{\mathrm{m}}$

Savoy, C. (1993). A yearly mental training program for a college basketball player. Sport psychologist, 7(2), 173-190.

Scales, W. D. (1998). The effects of mental imagery on tennis serving performance across race. Dissertation Abstract, UMI Co.,ProQuest, Michigan State University.

Schmid, A., \& Paper, E., (1993 ). Training strategies for concentration in J.M W Williams (2 Ed) Applied sport psychology: personal growth to peak performance: May Field Publishing, Company (pp. 262-273).

Schomer, H.H. (1986). Mental strategy and the perception of effort of marathon runners. International Journal of Sport Psychology, 17, 41-59.

Slone, L. A. (1993). The effects of mental practice and physical practice on the 
improvement of the golf swing: Dissertation A bstracts International.

Straub, C. (1996). Effects of a mental imagery program on psychological skills and perceived flow states of collegiate wrestlers. Unpublished master's thesis, Miami University, Oxford, $\mathrm{OH}$.
Takahashi, M., Van Raalte, J. L., Mizuochi, F.1, Tanaka, N., \& Kamiwazumi, J.(2009).Relationships Between Self- Talk and Anticipation Responses in Receiving Tennis Serves. The 12th ISSP World Congress of sport psychology, Marrakesh. 